\title{
An inventory of soils and soil suitabilities in West Irian. II $\mathrm{A}^{1}$
}

\section{H. SCHROO}

Chief soil scientist, from 1956 to 1962 , in the former Government of Netherlands New Guinea

Part II A: Specified information

\section{Summarized results of soil surveys in special localities}

\subsection{Explanatory remarks}

In this concluding chapter 4, a summary will be presented of the main types of soil and their suitabilities which have been met with in the past in the 31 surveyed areas (objects) that are indicated in FIG. 1. For agriculturists starting to work in West Irian in the next future, it certainly will be of value to be informed briefly about those localities where previous investigators have been successful in their search for suitable soils and where their findings have been disappointing.

In Part I it has been explained that, up till 1962, the main objective of most exploratory-, reconnaissance-, and more detailed soil surveys have been the inventory of those soils, occurring in newly or partially developed areas, which were suitable for agricultural use in general and for production of native cash-crops in particular. Most of these surveys were carried out in relatively flat, alluvial terrains and their nearest hilly surroundings. These surveys yielded a considerable number of soil complexes, soil series, soil types and soil phases as follows from the general data already presented in the preceding chapters. An enumeration and discussion of all these soil units would lead far beyond the intended scope of the present paper. For the same reason the author had to refrain from presenting detailed descriptions of soil profiles. For such information the interested reader is referred to the elaborate data contained in the original reports with soil maps which are listed in ANNEX II. The present summary facilitates the access to these original sources of pedological information.

In the following paragraphs the $\mathbf{3 1}$ areas where soil investigations were made, are grouped according to their geographical or geomorphological relationship. The geological setting of each object (or group of objects), will be discussed only as far as such is essential for the proper understanding of pedological facts.

Most attention will be paid to those soil units which occupy a sufficiently large area and which have been judged suitable in terms of present and efficient agricultural use. Soil suitabilities in terms of future use will be mentioned tentatively, because the technical and economical aspects of such use hold a strong element of speculation about future possibilities: measures for land improvement and better practices of land use which were not possible up to 1962, may or may not be realized in later stages of agricultural development of West Irian.

1 Part I, including Figures 1, 2 a-b, 3 and Annexes I and II, was published in Vol. 11 (1963) No. 4 (Aug.), p. 308-333, of this Journal. Part II B, including Figures $11-15$ and the continuation of Annex III, will be published in the next number, viz. Vol. 12 (1964) No. 1 (Feb.).

Received for publication 1st July, 1963. 
It will be noted that important soil series which come under discussion in the following paragraphs, will be given a geographical name in addition to the more descriptive names used in the original reports. They occur under that denomination and the number of the "object" in the list with analytical data, presented in ANNEX III. In the text, these important soil series will also be indicated, whenever useful, with the same symbols as have been used in the original soil maps.

4.2. North-coast section east of the Sermoriver (Objects 1-4) Soil conditions in this area may be discussed best with the aid of the geological sketch presented in FIG. 4 and borrowed from ZWIERZICKI (1921). In this area, situated between the Sermo river in the west and the Australian border in the east, the Sentani lake takes up a central position. Before the general uplift of the north coast the lake was in open connection with the sea but lies now at an elevation of $74 \mathrm{~m}$ above sea level. With the exception of the Cyclops Mountains, north of the lake, which consist entirely of igneous rock, the remainder of the area is built by folded, young Tertiary sedimentary rock such as marls, sandstones, mudstones and conglomerates. The elevated, Quaternary coral limestones mark the extension of the former off-shore zone of a shallow coral sea. In this landscape larger and smaller

FIG. 4. Geological sketch map of the north-coast section east of the Sermo river and the hinterland of Hollandia

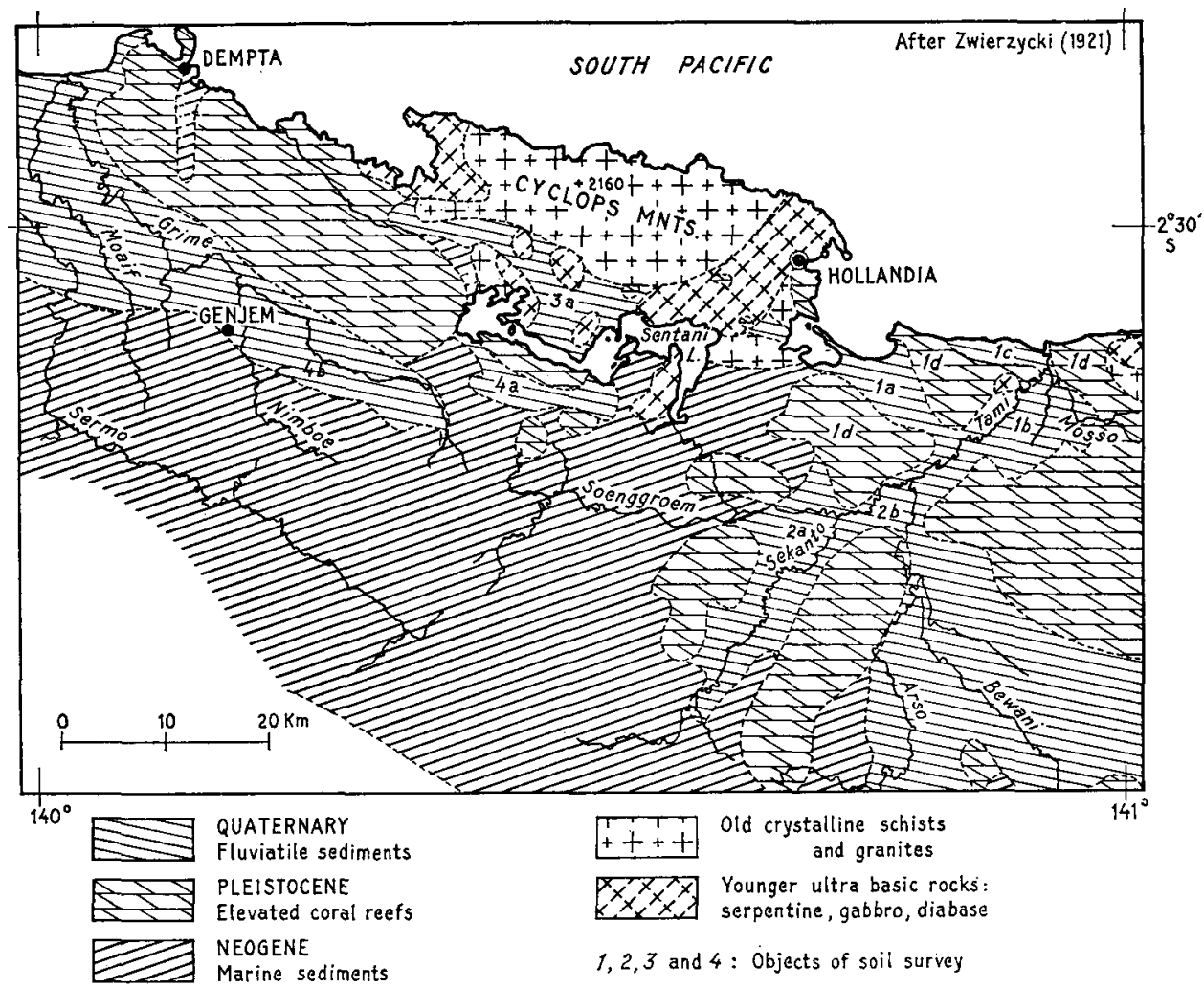


alluvial terrains are found. In the higher parts, as is the case in the Grimé and Sekoli plains, the rivers have formed terraces which correspond with successive phases of the tectonic upheaval of the land. In most of the lower-situated terraces, floodplains and sedimentation basins, swampy conditions prevail during the greater part of the year. Where the hills rise from these alluvial flats, a fringe of alluvial fans alternated by zones of hillside colluvium may be found. These landscape elements are also typical for the narrow alluvial strip of land which separates the Sentani lake from the Cyclops foot-hills and which presents the only agricultural hinterland of the capital Hollandia (now named "Kota Baru"). The substrata of these alluvial fans consist of boulders and gravel in which the river waters seep away so that little water flows through the river's lower course during the drier months of the year. At the lower end of the fan, this water reaches the surface of the fan again, causing swampy conditions which are ideal for the growing of sago (Metroxylon sago). Only during prolonged rainy weather, the rivers may overflow their alluvial fan and cover it with fresh sediments.

\section{Object 1: The Holtekang-Tami-Skou area}

This area of about 23.000 ha was surveyed in 1960 (Report 1.1 in ANNEX II). Three main areas of flat relief can be distinguished and are indicated in FIG. 4:

1a. the Holtekang plain which presents the former flood-plain of the Tami before this river took a more northeastern course;

1b. the present flood-piain of the Tami and its affluent the Mosso;

1c. the coastal plain near the village of Skou.

Each of these areas, as well as the total area of Object 1, is surrounded by mountainous, badly dissected karst landscape which will remain undiscussed because it is unsuitable for agricultural purposes.

In the Holtekang plain (1a) two soil series have been distinguished, viz. the Old Tami, silty clay (symbol A.1.1) occurring in the coastal half and the Old Tami, silty clay loam (symbol A.1.2) which is found in the more inland half of the Holtekang plain. A standard analysis of both series is presented in ANNEX III and suggest a good soil fertility.

The clay fraction of both soils proved to consist half of montmorillonite and half of illite clay minerals. The entire area of about 7.200 ha is rather marshy to swampy, due to the poor internal drainage of the heavy soils and, also, due to very inadequate surface drainage prevailing in the greater part of this area. Nevertheless, it is most likely that the Holtekang plain offers interesting agricultural possibilities for the future if perfect water control in these fairly level terrains can be ensured by means of large-scale technical improvements.

In the Tami-Mosso plain (lb) very fertile, young alluvial soils are found which have been divided into a Tami- and a Mosso series (symbol A.2). These soils cover some 6.000 ha in an area which is very wet and difficult to drain as it serves as the natural outlet for the flood-waters of both rivers. For this reason it is doubtful whether these soils can be recommended as suitable soils in terms of future use.

Suitable soils in terms of present use are only to be found in the coastal plain of Skou (1c), which is made up of beach ridges and beach swales. In particular the slightly elevated, reddish-brown coloured, backshore beach sands which occupy some $1.200 \mathrm{ha}$, are suitable soils. They are already used by the villagers of kampong Skou for the growing of food-crops. This is done in the usual wasteful manner of shifting 
cultivation and it stands to reason that a more efficient use could be made of the agricultural potential of these soils. A standard analysis of this series, the Skou, reddish-brown, (loamy) beach sand (symbol K.1.2) is presented in ANNEX III. The other two Skou series (K.1.3 and K.1.4) are too wet because of their low position in the terrain.

\section{Object 2: The Soenggroem-Sekanto-Arso-Tami plains}

The Soenggroem-Sekanto plain (2a) and the Sekanto-Arso-Tami plain (2b), indicated in FIG. 4, have been surveyed in 1942. Hydrological conditions in both areas proved to be very unsatisfactory because the natural drainage of the terrains involved is poor and the rivers overflow often and rapidly. Even in the driest months of the year it was found that most of the terrains was covered with a foot water. Only the river levees and higher grounds surrounding the adjacent limestone hills remain dry but do not form a significantly large area for agricultural enterprise.

\section{Object 3: Hinterland of Hollandia}

The actual hinterland of the capital Hollandia that offers agricultural possibilities is restricted to the narrow alluvial strip of land which is found between Sentani lake and the steep foot-hills of the Cyclops Mountains. It can be reached by the main road which leads via Hollandia-Binnen to Sentani airfield and Dojolama. It branches off with a jeep-trail towards Sabron and Depapre. In this area (3a), soil suitabilities are rather limited because the covering layers of sand or sandy loam, overlaying the coarse substrata of the many alluvial fans, are mostly shallow and interspersed by irregular patterns of lithosols. Quite a number of detailed soil surveys have been carried out for the benefit of small-farmers in this area. Depth and texture of the solum and also the mineralogical composition of the parent material were the main criteria for these detailed soil maps. Most soils are susceptible to drought except the soils near the border of Sentani lake which are marshy.

The fertility of both upland- and lowland soils north of Sentani lake is governed mainly by the mineralogical composition of the participating parent materials.

Two groups of rock can be distinguished in this respect, as can be deducted from FIG. 4. The ultrabasic serpentine rock and serpentinized Harzburgite prevail near Tanah Merah Bay and also east of the line Sentani-Ifar. They form the dusky red (10 R. 3/4) mature latosols, often with a distinct layer of plinthite in their subsoil, which cover the mountainous area around and further west of Hollandia. This Hollandia latosol on serpentine has also been described by MOHR and VAN BAREN (1954). These soils are not only infertile, but they are also toxic to a certain extend to a number of plants and trees, as they contain harmful concentrations of free chromiumand nickel ions. This fact has been proved by RoBinson (1935), Birrell et al. (1945), and CHANg (1953) for similar soils elsewhere in the world. The soils are avoided by the natives who prefer the steep hillside soils of the scattered, elevated coral-limestone outcrops for the growing of their subsistence crops. The soils can be somewhat improved by liming and addition of phosphate whereas also their surface layer, enriched with forest humus, seems less alien to plant life.

On the older, quartzitic group of parent rocks comprising crystalline schists and granites, latosolic types of soil are developed which are not very fertile either and are susceptible to erosion.

The soils show brighter colours than the serpentine soils, namely from red (21/2 YR. 4/8) to reddish-brown (5 YR. 4/6). In areas where both groups of parent rocks are inter- 
mingled, the bright red colour and the presence of white quartz stones at the soil surface mark the weathering soils of the quartzitic parent rock, as can be observed along the roads to Rheinouwe and Ifar.

The alluvial parent materials found in area $3 \mathrm{a}$, are often composed of debris derived from both groups of parent rock. They contain varying quantities of hillside colluvium, next to fresh rock fragments, quartz, ironoxide, muscovite, chlorite and other characteristic minerals. Apart from textural inadequacies, these alluvial soils show certain distinct mineral deficiencies as well. Vegetables and fruit-crops are generally poorly developed unless organic manures, lime and fertilizers are used. The Jabau, sandy loam, a soil series which is found at Kota Nica Agricultural Centre, may serve as just one example out of the many soil variants. This soil has a neutral to slightly alkaline reaction because of large amounts of magnesia. It is deficient in lime and potash, whereas also distinct symptoms of zinc deficiency for cocoa and citrus has been described by ScHROo (1959). A standard analysis is given in ANNEX III.

\section{Object 4: The Grimé- and Sekoli plains}

The Sekoli plain (4a) and Grimé plain (4b) in the Nimboran area south of Sentani lake (FIG. 4), were surveyed for the first time in 1939 and were partly re-surveyed in 1958. The plains are relicts of a Tertiary sedimentation basin which was first filled with marine sediments and later on with fluviatile sediments. Intermittent elevations of the entire area caused rivers to cut into these sediments. During this period flood-plains were formed at different levels, remnants of which are still present as extensive terraces. The lower terraces are very wet, the higher ones relatively dry. In the Sekoli plain, the terraces are formed separate of those in the Grime plain and such by different rivers. The higher grounds in the Sekoli plain are found in its southern part and in the transitional zone, westward, to the Grimé plain. Here, the dominant soil serie may be called: Sekoli, very dark grey, silty clay (symbol No. 8 in the original report 4.1). It is a deep, reasonably fertile soil suitable for present agricultural use, provided that on its 3.500 ha of land surface a good drainage is ensured. A standard analysis of this soil series is presented in ANNEX III.

The lower terraces of the Grimé plain, northwest of the confluence of the Nimboe river with the Grimé river, are repeatedly flooded by the overflowing Grimé river, which cannot digest the large masses of water coming down from the uplands in the south. The higher terraces east of the Nimboe river and of the village Genjem are fairly dry during the drier months of the year, i.e. from May to November. In the wet season, however, this part of the plain is also very wet. This is because the excess of rainwater accumulating at the soil surface cannot flow away easily as the natural drainage channels are bordered by low levees. The area is thus not really flooded but just marshy.

Two soil series are distinguished which are carefully described and characterized by a great number of analytical data in the original reports 4.4 and 4.5 . These soils obtained much attention because of their prevailing occurrence in the 1.200 ha of land which were to be planted with cocoa in the projected Cocoa Development Scheme Nimboran.

The Janim, deep, very dark greyish-brown (21/2 Y.3/2), silty clay loam (symbol 6) is found in the higher terrains along the rivers, whereas a variant (soil type No. 5) is somewhat heavier and occurs in the lower parts of the terrain. The soils are fertile, though slightly alkaline in the surface layer. They contain free lime in their subsoil and are definitely deficient in potash. Standard analyses of these two variants (No. 5 
and 6) of the Janim, silty clay loam are presented in ANNEX III. X-ray analysis revealed that the clay seperates of these soils are made up of $50-40 \%$ montmorillinite, $50-40 \%$ illite, $5 \%$ kaolinite and $5 \%$ quartz.

The soils are not suited for present use but are considered very promising when properly drained and protected against inflow of surface water from the adjacent hills. These reclamation measures require high investments. Near Genjem, cocoa is grown succesfully on soils having similar parent material but which are of lighter texture having better internal drainage.

\subsection{North-coast section east of Sarmi (Object 5)}

The north coast east of the village Sarmi has been surveyed on an exploratory scale of $1: 250.000$ for the first time in 1951. Only three soil complexes were described, viz. yellow, quartzitic hillside loams in the southern hills; yellowish-grey, mottled silty loams of the lowland swamps and yellowish-brown sandy and loamy soils which occupy slightly elevated, moist to dry areas within the lowland swamps. The hilly country that borders the coastal flat on the south, is part of the Northern Dividing Range which is built of Miocene and Pliocene sedimentary rocks mentioned already in the previous paragraph. The hills rise steeply from the plain and are heavily dissected by erosion. The geography of the area, together with the approximate borderline between lowland and hills, is depicted in FIG. 5a.

FIG. 5a. Geographical sketch map of the north-coast section east of Sarmi

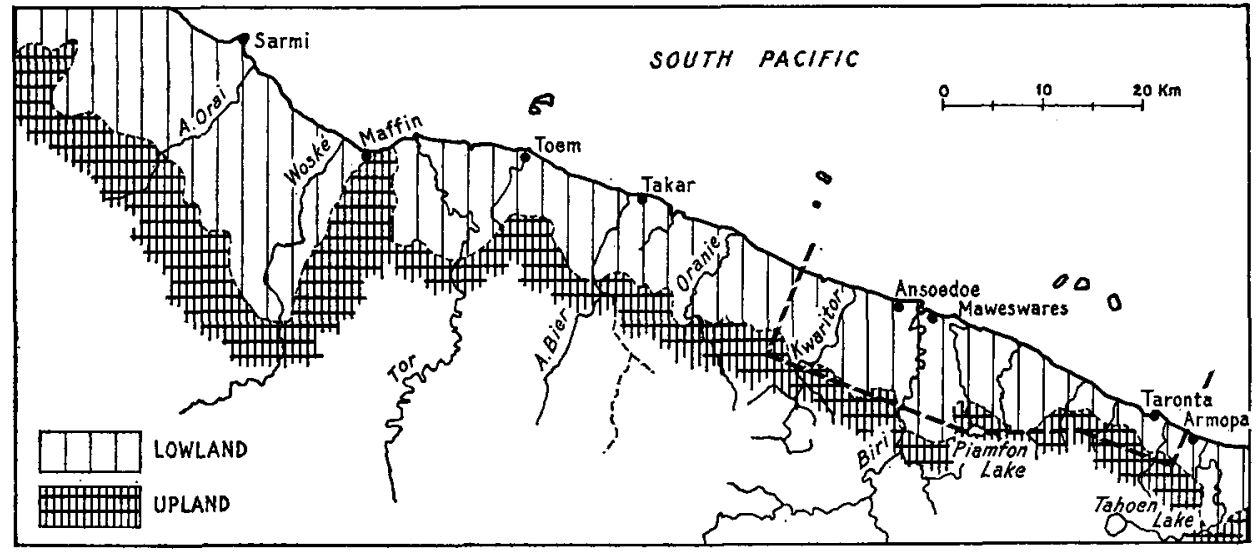

Originally, the lowland presents a sandy sea-floor that was slowly raised above hightide level in Post-Tertiary times. Inside the off-shore bar which developed at low-tide level, lagoons were formed which gradually filled with sediments carried down from the southern hinterland by the young and turbulent rivers. The river sediments are predominantly loamy, the coastal sediments sandy. Subsequently, a slow rise of the area caused further growth of the land and an outward migration of the beach ridges. The precise location of the drier soils in the matrix of marshy and swampy land, needed a more detailed survey. Consequently, three sections of land along the mouths of the Orai-, Woské- and Tor rivers were re-surveyed on a mapping scale of $1: 20.000$ in 1958; the results are described in Report 5.4. 
During this survey, 14 different soil types were mapped, namely: one limestone soil; two recent beach-sand soils; three older, brown to reddish-brown sandy soils; two types of dry, sandy loams; two loamy soils of heavier texture in marshy terrain and, finally, four silty loams in the swampy terrain depressions. In these three sections of land, which totally measured 3.200 ha, about 100 ha of recent sandy beach soils which were suitable for growing subsistence crops were met with. The remainder of the area was suitable only for the growth of sago palms. Therefore, there is little point in saying much more about these soils.

In 1960, an additional 27.000 ha of coastal land between Betaf and Armopa were re-surveyed on a mapping scale of 1:50.000 (see report 5.3). Here again three soil complexes were distinguished, namely: coastal sedimentary soils, fluviatile sedimentary soils and residual hill soils.

The first complex (symbol K), comprised the recent sandy beach-soil series $(\mathrm{K} .1)$ the old, loamy to sandy beach-soil series (K. 2) and the loamy lagoon-soil series (K. 3). The second soil complex (symbol $\mathbf{R}$ ) comprised the sandy river-ridge soil series ( $\mathbf{R}$. 4) and the loamy river-ridge soil series (R. 5).

Finally, the third complex (symbol H) was made up of hill-foot soil series (H. 6) and the hillside soil series $(\mathrm{H} .7)$.

Each of the seven soil series denoted on the soil map was sub-divided into a dry, a moist and a wet sub-series, whereas also four depth phases of profile development in these very immature soils were distinguished, according to the depth reached by the brownish colouring of the surface soil. The dry soils of series $\mathrm{K} .1$ cover almost 1.100 ha and are very suitable for the growth of coconut palms which thrive excellently here.

The drier soils of the old, loamy to sandy beach soils (sub-series K. 2.1), which are suitable for growing cocoa and coffee, do not occupy much more than 200 ha near the kampong of Foja, east of the Biri river, and another 400 ha are found in smaller lots of land in between the swamp soils southeast of Taronta. Only part of the moist soils of sub-series K. 2.2 can be converted into suitable agricultural soils through relatively simple drainage measures. It is recommended to select for this purpose only the deeper soil phases of the sub-series. About 1.100 ha of these soils are to be found in the area south and east of the kampong Anoes. The soils of series K. 2 are reasonably fertile but their potash content is rather low. The natives normally use these soils for two years at a stretch and rest them under fallow for

FIg. 5b. Hydrological sketch map of the Betaf-Armopa area

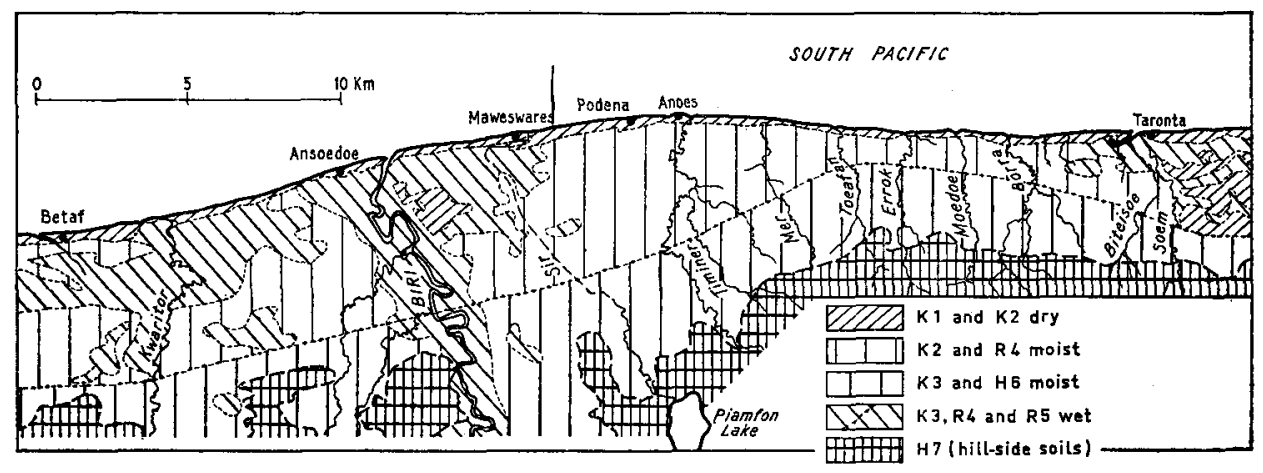

Neth. J. agric. Sci., Vol. 11 (1963) No. 5 (November) 
not more than five years, which is in accordance with the favourable analytical characteristic presented in ANNEX III. The fertility of the moist lagoon soils (subseries K. 3.2) is even somewhat higher. These soils, together with the river-ridge soils (R. 4.2) are in need of more elaborate and expensive drainage measures in order to improve them. A further study of the 9.000 ha involved may ascertain whether the presumption is right that here large acreages can be reclaimed and turned into land which is suitable for the production of cash-crops.

For the approximate position of the main hydrological types of land occurring in this vast coastal area, the reader is referred to the sketch in FIG. 5 b.

\subsection{The islands of Japen, Biak and Noemfoer (Objects 6-8)}

The three islands of Japen, Biak and Noemfoer are only geographically related to each other through their position in the north of the Geelvink Bay. The geology, geomorphology, soil types and the agricultural potential of each island are quite different and thus they will be discussed separately.

\section{Object 6: The island of Japen and Koeroedoe}

The island of Japen is about $160 \mathrm{~km}$ long and $24 \mathrm{~km}$ wide. Its surface is mountainous with a general east-west trend. In the middle of the island heights run up from 800 to $1500 \mathrm{~m}$. North-south corridors across the island are practically absent and valleys are small and narrow. The coast is generally rocky whith fringing coral reefs. Coral-reef ledges are also found at the borders of the terraces in the hills which prove Sub-Recent elevations of the island.

Japen is an anticline and has a core of igneous rock which include Tertiary basalt, andesite and slate, with schist, gneiss and some granite in the centre. Its northern flank is underlain by Pliocene sediments and its southern flank by Miocene limestone. Predominantly coarse-clastic beds consisting in the eastern part of the island of clayey greywackes, lignitic marls and calcareous claystones overlie the limestone unit. Their equivalent in the western part comprises bluish foraminiferal marls and claystones, alternating with greywackes and conglomerates rich in volcanic components.

The few and fairly small coastal plains along the north coast, of which the plain of Jobi is the largest, are very difficult to reach by land and are equally inaccessible from the seaside because of the dangerous surf. Along the south coast there are a greater number of coastal plains where good arable land can be found. From west to east, the most important plains are those of Wooi (450 ha), Maraoe (400 ha), Ansoes (600 ha), Papoema-Kanawe (1000 ha), Areapi (1200 ha), Seroei (820 ha), Menawi (1080 ha), Wadapi (800 ha), Randawaja (2000 ha), Korembobi (300 ha) and Soemberbaba ( $800 \mathrm{ha})$.

From the total of about 8.700 ha of suitable land, two third are actually found in the plains and one third in the surrounding hills. Most of these plains are enclosed from the landside by foot-hills of the main mountain range and they are separated from the sea by a sand bar of beach. Behind this ridge of coral sand or gravel a swampy area is mostly found, which gradually merges into higher and drier soils. Practically all of these plains were build by young and short rivers which have filled the original bays with erosion materials derived from various types of rock occurring in the mountains.

The mineralogical composition of these sediments is generally rich in plant nutrientscontaining minerals, although this composition may vary from one river sediment to 
the other. The subsoil of these coastal plains is built of coarse-textured sediments like coarse sands and gravels. These layers are usually closer to the surface when approaching the seaside end of the plain. Closer to the hillside they are thickly covered with finer sediments which range from sandy- to clayey loams. Actually, most plains are constructed as alluvial fans. However, due to the tectonic raise of the islands, the rivers have cut terraces in their alluvial fans. Very often two to three terraces are moulded in the sediments whereas levees may be found along the river at its lower end. The drier hillside soils, the higher terrace soils and the levee soils are very suitable for the planting of cocoa provided that coarse sediments do not reach close to the surface. By the end of 1961 , about 700 ha were planted with cocoa in the island of Japen. Some of these native plantations produced as much as $750 \mathrm{~kg}$ dry cocoa per ha when 6 years old.

The island of Koeroedoe, east of Japen, is a continuation of the north flank of the Japen anticlinal, and measures 11 by $3 \mathrm{~km}$. Maximum elevation is $200 \mathrm{~m}$. Its northeast coast is flat; elevated coral terraces form small flat-topped hills in the interior of the island. About 800 ha of suitable soils are to be found here, 300 ha of which are situated in the coastal plain. The Koeroedoe soils are rated less fertile than the Japen soils, the mineralogical composition of sand separates derived from various soil samples proved to consist predominantly of quartz.

\section{Object 7: The island of Biak (FIG. 6)}

Biak is the larger of the Schouten Islands and is about $80 \mathrm{~km}$ long by $40 \mathrm{~km}$ wide. Soepiori, the smaller island northwest of Biak, has never been visited for soil-survey purposes and will therefore remain undiscussed.

On Biak only the area south of the line Wardo-Siabes-Biak, i.e. the southwestern area, has been surveyed (reports 7.1 and 7.2), whereas also about 6.000 ha in the

FIG. 6. Geological sketch map of the island of Biak

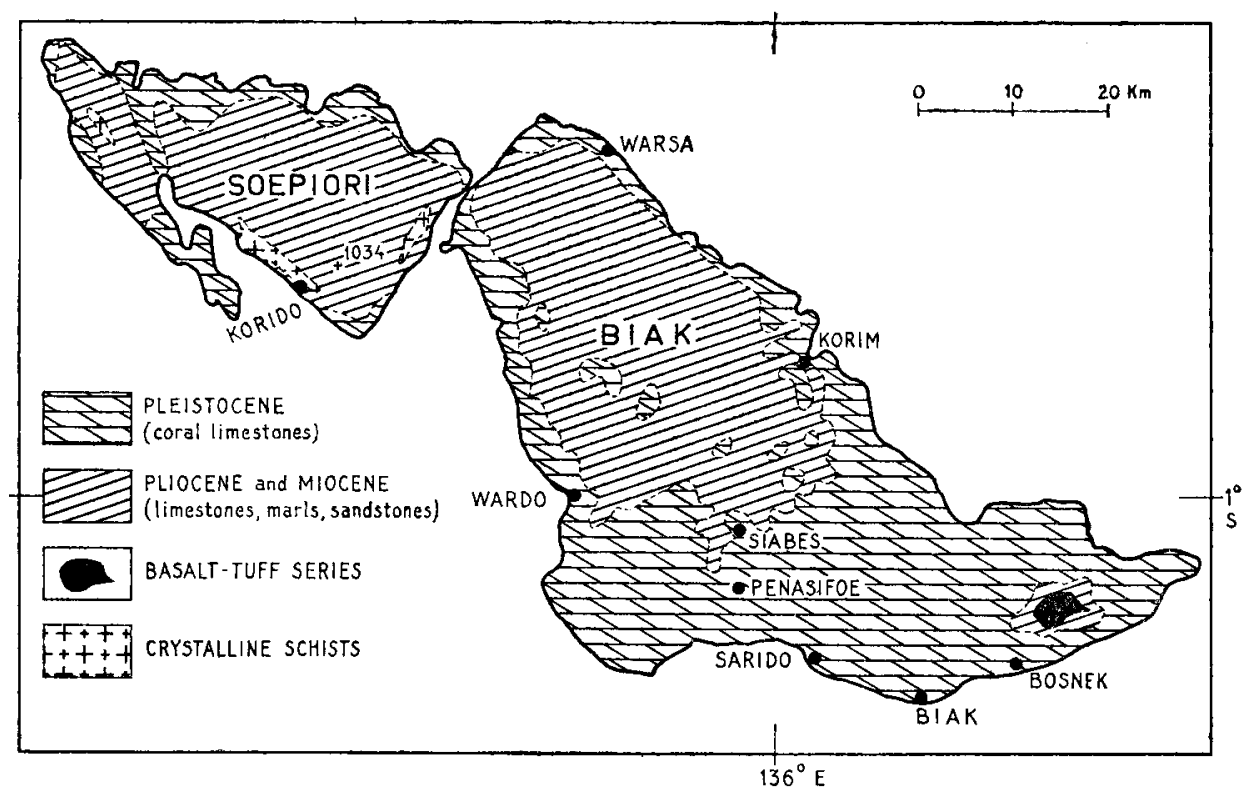


so-called "Bosnek area" were surveyed in connection with the extension of the native copal plantations (report 7.3).

The northern half of the island is covered with calcareous sediments of MiocenePliocene age. The southern part is covered with a thick layer of more than $70 \mathrm{~m}$ of coral limestones of Pleistocene age. These elevated coral terraces dip slightly to the south. They attain elevations from 200 to $300 \mathrm{~m}$ along the north coast and of about $160 \mathrm{~m}$ on the south coast.

In this southern area, hard limestones of biohermal reefs alternate with softer, gritty beds of cemented rock waste, as may be expected to occur on a former shelf of a coral sea. These marine structures are still very clearly visible on the aerial photographs of that area, not withstanding the secundary karst morphology and the forest cover. Practically all water courses are subterraneous, as distinct from the northern area where rivers cut deeply into the soft Neogene sediments.

In the southern karst area, the reef structures (pinnacles, dome-like hills, dolines and uvalas) alternate in a very irregular pattern, as seen from the air. Only in the depressions of this terrain soils are found developed on limestone which are sufficiently deep to warrant successful cropping.

In all depressions the deeper soil phases are found in the centre and the shallower phases towards the periphery of the depression. The depth of the solum may reach several metres in the centre of the smaller depressions or dolines. In the larger depressions, however, the solum seldom attains a depth of more than $1 \mathrm{~m}$. The shallow soil phases of one foot depth are suitable only for the temporary growing of subsistence crops; such soils are exhausted within one or two years. Large areas of southern Biak, which are now under shrub, have been exploited in this way by shifting cultivation.

The deeper soil phases, with a solum of more than $0,75 \mathrm{~m}(21 / 2 \mathrm{ft}$.$) , are probably$ suitable for the growing of cocoa although there is no definite evidence to prove this judgement. In certain localities, apparent on the aerial photographs, larger areas of several hundreds hectares with concave relief and deeper soils can be found, as it is the case near Penasifoe, south of Siabes, and also between Siabes and Wardo.

The profile of these limestone soils is generally rather undifferentiated. Their organicmatter content is medium-low. The upper part of the solum is mostly a silty (clay) loam, whereas the lower part often tends to be a silty clay that may contain small, soft iron concretions. The percentage sand is seldom more than 10 and mostly around 5 to $6 \%$. The transitions towards the underlying parent limestone rock is rather abrupt. Sometimes, a sandy to gritty transitional layer of 10 to $20 \mathrm{~cm}$ is found which is also the only layer containing free calcium carbonate. The (moist) Munsell colours of these soils vary from dark reddish-brown (5 YR. 3/3) on slopes and elevated spots to yellowish-brown (10 YR. 5/6) in the lower parts of the terrain. Their structure and permeability are excellent, their water-storage capacity fairly good but this feature depends mainly on the depth of the solum. The shallow phases are subject to desiccation once the vegetation cover is removed. In very low terrain depressions, where subterranean water may reach up to the surface through cracks in the limestone, a dark greyish-brown (10 YR. 4/2) hydromorphic soil phase may be formed which is unsuitable for agricultural use.

Although the physical properties of the well-drained limestone soils are excellent their fertility is not very high. The soil's reaction lies between $\mathrm{pH}=6,0$ and 6,5 but may be more acid in some instances. The lime content of soils west of Siabes tends to be higher and lies between 2000 and 4000 p.p.m. available $\mathrm{CaO}$ whereas the 
soils east of Siabes (Penasifoe series) usually have a lower lime content.

Magnesia figures in the acetic-acid extract are also low, but are sufficient for plant nutrition. The potash content of these soils is insufficient, specially if the percentage of total $\mathrm{K}_{2} \mathrm{O}$ is taken into consideration. Naturally, these coral limestones do not hold appreciable mineral-potash reserves. For the same reason, deficiencies of certain minor elements are likely to turn up after prolonged cropping.

The phosphate content of these soils is extremely high; the soils east of Siabes seem to have much higher total-phosphate figures with an average of about $12 \%$, whereas the limestone soils in the Wardo-Siabes area tend to analyze not more than $6 \%$ which is still extremely high. This striking aspect of coral-limestone soils, described by Schroo (1963) will be discussed in some more detail when dealing with the Ajamaroe soils (Object 21). A standard analysis of the Siabes-Penasifoe limestone soil is presented in ANNEX III.

The "Bosnek area", north-east of the kampongs Soriar and Bosnek, and $30 \mathrm{~km}$ away from the town of Biak, is quite different. It is a plateau-like landscape that rises abruptly from the surrounding karst landscape and attains an average altitude of $80 \mathrm{~m}$ above sea level.

In Pre-Tertiary times, it must have been an island which was made up of schist, covered with basalt flows and, subsequently, with layers of basaltic tuffs in early Tertiary periods. These parent rocks are locally serpentinized. At its periphery this outcrop of basic volcanic material is covered by Tertiary limestones and various series of marl according to Patchett and Hottinger (1937). An area of 6.000 ha has been mapped on a scale of $1: 20.000$ (Report 7.3) in order to investigate the possibilities for a further extension of the present native plantations of Agathis labillardieri, a coniferous tree species which is tapped for "copal". On account of the underlying parent materials, three soil complexes were distinguisted:

yellowish-red clays on basaltic tuff (complex A)

yellowish-brown clays on the Soepiori limestones (complex C) and on Korundori marls (complex B)

hydromorphic clays in alluvial areas (complex $\mathrm{C}$ ).

The first-mentioned soil complex presents the real "Agathis soil" on which these trees grow extremely well, provided that they are not over-tapped. When over-tapped, as frequently is practised by the native owners, the trees quickly die. The "Agathis soils" form a catenary soil complex of very poor and leached soils. They show bright-red colours (10 R. 4/8) on ridges and the upper part of slopes but more yellowish-red colours (5 YR. 5/8) on level terrain and the lower parts of slopes. Their clayey C-horizons are multi-coloured with red, purple, yellow and white mottles in which the original structure of the basaltic tuff is distinctly recognizable. However, all mineral components of this parent rock have been dissolved entirely, quartz, iron concretions and sometimes a few fragments of serpentine being the only recognizable mineralogical components of sand separates.

The predominant clay mineral proves to be kaolinite, with 10 to $20 \%$ gibbsite in addition. The soil's reaction is highly acidic and there is remarkably little difference between $\mathrm{pH}$-normal and $\mathrm{pH}$-exchange, as the weakly developed absorption is almost void of bases. Accordingly, the soils are very deficient in lime; magnesia- and potash contents are also low, whereas Truog-values for easily soluble phosphate are nil. Total-phosphate contents, however, are rated medium-low. An analysis of an average surface soil is given in ANNEX III. Under Agathis forest, there is a well-developed organic surface layer with a fairly high content of acid humus. At some places a 
real podsol profile was found underneath an uprooted Agathis tree. In most of these soils sub-surface horizons of iron- and humus accumulation may be found in all degrees of development although a real ironstone layer only occasionally occurs in flat terrain. In most profiles small, sharp-edged fragments of cemented siliceous material are found which are still soft in the C-horizon but very hard, buff- to redcoloured in the B-horizons. The soil complexes $\mathrm{B}$ and $\mathrm{C}$ are of less importance and remain, for briefness sake, undiscussed.

\section{Object 8: The island of Noemfoer}

The island of Noemfoer which measures 20 to $23 \mathrm{~km}$ across, was surveyed in 1954 . A vegetation map and a soil map, both on a scale of $1: 63.360$ are presented in Report 8.1. After having dealt with the limestone soils of south Biak in some detail, it is no use discussing the soils of Noemfoer as they are the same type of corallimestone soils.

The island is entirely built up of elevated coral-limestone terraces which are formed from $2 \mathrm{~m}$ up to $150 \mathrm{~m}$ above the present sea level. Only, below the level of $60 \mathrm{~m}$ the terraces have accumulated enough soil at their surface worth speaking about. Practically the whole island is a rugged karst area without water flowing along its surface. Fresh-water wells are found at sea level along the island's periphery where also the native settlements are found.

Apart from some 400 ha of coral beach sands which are suitable for growing coconut palms, there is altogether only a scattered area of about 2.500 ha of arable land covered with reddish-brown limestone soils which are partly shallower, partly deeper than $50 \mathrm{~cm}$. All this land is under cultivation or has been used for the growing of food-crops in the past.

\subsection{The Waropen coast (Object 9-11)}

The coastal area west of the Mamberamo river depicted in FIG. 7, is largely covered by Mangrove- and Nipah forest in the extensive tidal swamps along the coast and by sago forest and fresh-water swamp forest in the broad belt of swamps more inland. The width of this swampy area may vary considerably from a few to more than $30 \mathrm{~km}$. Especially between Waren and Napan this swampy area extends very far inland and reaches a width of $50 \mathrm{~km}$ along the Wapoga river. Locally, and particulary between Napan and Nabiré, the mountains of the interior reach almost to the coast.

North of the Waipoga river, these mountains form the extension of the Northern Dividing Range and are built up by Miocene and Pliocene sediments. Miocene sediments include the typical massive, pinnacled limestones overlain by tuffaceous conglomerates, sandstone, sandy clay and Globigerina marl. Pliocene sediments include sand, silt clay, sandstone, lignite, shale and conglomerates.

South of the Waipoga river, the mountains that border the coastal area to the east and south belong to the Central Mountain Range, the bedrock of which is yet greatly unknown. According to the data, presented in our FIG. 3 (Part I), Mesozoic and Paleozoic bedrock are to be expected here and also Tertiary outcrops of volcanic rock in addition to the Tertiary sediments mentioned above.

\section{Object 9: Coast Waren-Paradoi}

In the beginning of 1962 a reconnaissance survey of about 20.000 ha on a scale of $1: 100.000$ was carried out in order to investigate whether sufficient dry grounds 
Fig. 7. Geographical sketch map of the Waropen coast

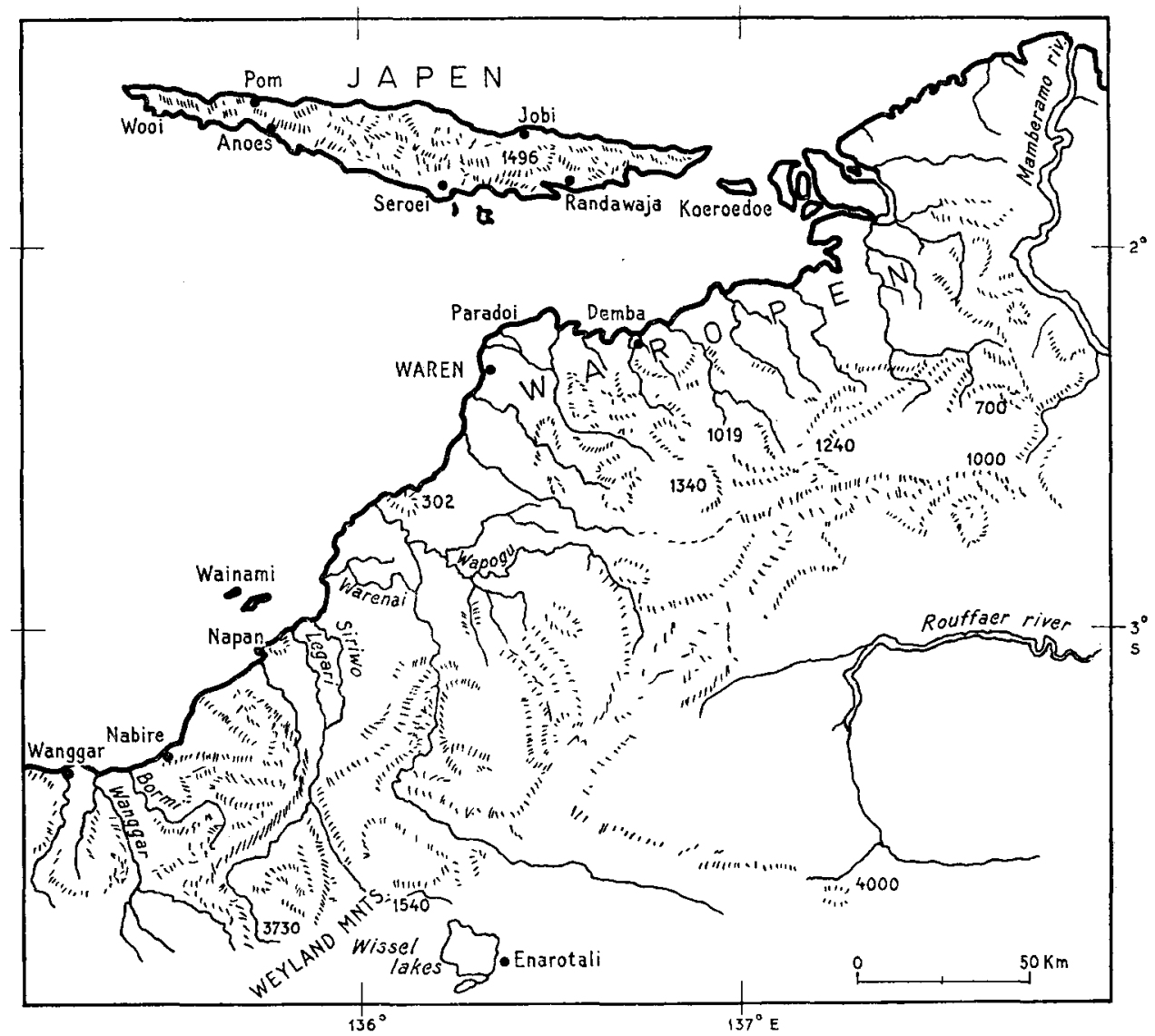

were to be found in the hinterland of the village Waren. This village is situated on a mound of higher ground which forms an island in the midst of extensive swamps. Although the survey was accomplished, the final report was never finished and so, little can be said in detail about the soils in that area.

However, the general results of the survey were very disappointing as had been anticipated beforehand after analysis of recent aerial photographs of the area. Outside the Waren mound, only narrow strips of drier soils were found on the levees of rivers and on old river ridges which traverse the swamps east of Waren. Drier ground along the foot of the uplands to the south of the enormous swamps area could not be reached. This survey did not yield more than a thousand scattered hectares of dry soils near Waren, Paradoi and other smaller settlements near the coast.

\section{Object 10: The Legari plain}

The plain of the Legari river was surveyed as far back as 1940 as a part of the Javanese Resettlement Scheme of those years. The plain is a former shallow inlet of the sea which has been filled by the sediments of the Legari river. These sedi- 
ments are still underlain by coral reefs and beach sands. The lower end of the Legari river, about $8 \mathrm{~km}$ away from the kampong of Wainami on the coast, is surrounded by a vast tidal swamp. Going farther up stream, the Legari flows close along steep hills and mountain sides where crystalline schists are found along with limestones. In the steep and broken foot-hills bordering the Legari river to the southwest, the shallow and stony soils of the latosolic type can hardly be recommended for agricultural use. Likewise unsuitable are the 2.800 ha of surveyed peat soils which form an almost inaccessible swampy area on the north-east side of the river. The only soils which are suitable, after provisions have been made for protection against flooding, are the 800 ha of yellowish- to grayish-brown, loamy and sandy levee soils which are found on both sides along the river course. Likewise, another 2.000 ha of marshy, loamy basin soils may be found which are suitable for the growing of paddy, provided that flood hazards are effectively eliminated. Suitable soils in terms of present use are not available in this area.

\section{Object 11: Nabiré-Wanggar plain}

In the course of 1962 , about 40.000 ha of the alluvial plain situated between Nabiré and Wanggar were surveyed on a mapping scale of $1: 50.000$. The surveyed area which reaches about $15 \mathrm{~km}$ inland, includes the Quaternary deposits of the Wanggar and Boemi rivers and also part of the hilly country that borders the plain to the south and to the east. This hilly country is in fact the remnant of a very much dissected plateau made up of Plio-Pleistocene marine sediments of a calcareous type which has risen $200 \mathrm{~m}$ above the present sea level. The rise of the land is still in progress. Karst features are common in this landscape where calcareous bedrock predominates.

On the remaining level grounds of the former plateau, deep soils are found which are dark reddish-brown (5 YR. 2/2), sandy loams, grading below a depth of $40 \mathrm{~cm}$ into heavier silty loams which are yellowish-red (5 YR. 4/6) to reddish-brown (10 YR. $5 / 4)$. Neither surface soil nor subsoil contain free lime. On the hill tops and ridges, found below an altitude of $200 \mathrm{~m}$ along the periphery of the old plateau, similar soils are found which are seldom deeper than $100 \mathrm{~cm}$. On the hillsides very shallow soils or lithosols are found. The actual area of level soils is so much limited and dispersed that it altogether amounts to not more than a few hundred hectares.

Down in the plain, swamp soils are found together with marshland soils, the latter being divided into a soil complex of sandy loams, loams and clayey loams, and another soil complex of real sandy soils which are somewhat better drained. Neither of the two soil complexes have soils suitable for present agricultural use because of excessive wetness. The levee soils which are "gleyed" at a depth of $40 \mathrm{~cm}$ occupy an unimportantly small acreage.

The same can be said of the very narrow bar of beach sands that borders the plain along its sea frontier. These beach sands reach up to a height of 2 to $3 \mathrm{~m}$ above high spring-tide level. Only about 150 ha of suitable beach soils are here available. From this account it appears that the surveyed area of 40.000 ha did not yield suitable soils for present use worth mentioning.

\subsection{East coast of Vogelkop Peninsula (Objects 12-15)}

The east coast of the Vogelkop is characterized by steep beaches, generally of loose sand, pebble and boulders, with fringes of coral reefs in many places. Only few and relatively small swamp areas, grown with Mangrove- or Sago forest, are found along 
this coast. The high mountain ranges, having here a general northwest-southeast trend, draw very near to the coast. Locally, their foot-hills may even rise steeply from the sea. Here and there, bays formed in earlier eras, are now being filled with fluviatile materials by the short and braiding rivers, thus forming fairly small coastal plains of the alluvial-fan type. The sediments near the hills are coarse, and at the lower end near the shore silty loams are found which merge into real swamp soils. The latter are fenced off on the seaside by a sandy or stony strip of beach. The plains are characterized by the usual pattern of alluvial fans which have thick layers of gravel and boulders in the underground and often quite near the surface.

These layers are covered by wash soils which are deposited each time the river overflows its temporary banks. The wash soils are loamy and are intersected with numerous strips of river-ridge soils. The changing pattern of texture thus formed, renders the plain unsuitable for agricultural use on a large and mechanized scale. The small plots of individual soil types require adjustment to various types of land use.

The mineralogical make-up of the fluviatile material which is deposited in the plain, depends on the type of bedrock that has been eroded and carried away by the rivers in the highlands. In the general direction parallel to the coast, as well as in a eastwestern direction across the mountain ranges, a great variety of igneous and sedimentary bedrock is to be expected according to the geological data provided by ZWIERZYCKI (1930).

\section{Object 12: Coastal area, section Waren to Oransbari}

The Waren plain is the least fertile of the investigated areas. The Waren river traverses Jurassic bedrock which mainly consist of quartzitic shales and sandstones. The adjacent Momi plain is of somewhat better quality in that respect, as the Momi river reaches in her upper course into schists and granitic bedrock of Mesozoic and Paleozoic formations of the Namtoei Mountains. These Momi sediments are at least rich in potash but are lacking in lime and phosphate. It has been estimated that only 250 ha out of the total 5.000 ha are suitable for agricultural use whereas another 1.500 ha are judged to be suitable for pastures. The remainder of 3.750 ha is assumed to comprise unsuitable soils because of coarse texture, stoniness, wetness and general infertility. However, a detailed survey of the area has never been carried out.

The Ransiki plain which covers about 4.000 ha of land, borders on the Momi plain and is very fertile. The Ransiki river rises in the Arfak Mountains up north, and carries erosion material of very different composition such as shale, schists, andesite and gabbro. The soils are very rich in lime, magnesia, potash and phosphate. Here again, the texture of the soils varies considerably from spot to spot. The area was surveyed at a mapping scale of $1: 25.000$ in 1938, when 9 different soil types were distinguished and mapped. This classification was revised in 1954 , by which the soils were grouped into three series (Report 12.3):

1. greyish-brown, sandy river-ridge soils,

2. greyish-brown, silty and loamy river-wash soils,

3. brown, loamy hill soils on andesitic materials.

The latter series was divided into a shallow hillside phase and a deep phase on hill-foot colluvium.

About 2.000 ha are rated as suitable agricultural soils. Another 300 ha of shallow sandy and loamy soils, situated above the $30 \mathrm{~m}$ form-line, are suitable for pastures. 
Excellent results have been obtained in the past years with cocoa and coffee on the deep loamy soils. An analysis of a typical topsoil is presented in ANNEX III and proves the high fertility of this Ransiki soil.

The Oransbari plain is built by the rivers Moari and Biadi and some smaller rivers. The plain is narrow and not very suitable. About 2.400 ha were surveyed in 1951 on a mapping scale of $1: 63.360$ (Report 12.4).

Distinguished were: 1.400 ha of lithosols including 400 ha of stony beach sands, 400 ha of dry-, and 400 ha of marshy, sandy to loamy river-wash soils which are dissected by a great number of small water courses. The remaining 600 ha of swamp soils make up the balance.

Although the mineralogical composition of these soils warrant a high degree of fertility, it is the morphology and hydrology of the plain and its nearest surroundings that renders most of the soils unsuitable for present agricultural use.

\section{Object 13: The Anggi-lakes mountain area}

The Anggi lakes are situated at a distance of $35 \mathrm{~km}$ from the coast in a mountainous area between the Lina and Arfak Mountains at an altitude of $1900 \mathrm{~m}$ above sea level. The lakes are separated from each other by a flat saddle (height: $2.300 \mathrm{~m}$ ) and they are surrounded by high and steep mountains which reach a height of $3.000 \mathrm{~m}$. They consist predominantly of black, hard shales, slates, schist and finetextured sandstones of the Cretaceous and Jurassic formation. The area was visited by the pedologist WentholT in 1935 (Report 13.1).

The slopes of the mountains west of the lakes and also the saddle, are covered with podsolic soils developed on clayey shales. On more level terrain, there is a thick layer of acid organic matter, developed on top of the mineral solum. The soils are not suited for any agricultural use and they are avoided by the natives who are compelled to look for suitable soils far away from home.

North of the Anggi Giji lake, about 1.000 ha of fairly level terrain are found in the so-called "Irai plain", which is drained towards the lake by the Tisige river.

The larger part of this plain is covered with bog soil. The thickness of the grass peat, formed here under conditions of poor drainage and low temperature, varies from 80 to $150 \mathrm{~cm}$ and is underlain by an impervious bluish-gray, heavy loam. Food-crops thrive very poorly on this soil, mainly because of impeded drainage. About 300 ha of the plain, on the higher part along the Tisigo river, have suitable soils which are well-drained, yellowish-grey silts. These soils are practically the only ones which are used by the natives for the growing of food-crops, although the local need for suitable soils is far greater than a mere 300 ha.

The podsolic soils on granite, which are found east of the lakes are equally infertile. The soils are covered by thick layers of forest peat, which may attain a thickness of 75 to $100 \mathrm{~cm}$ according to WENTHOLT. Below an altitude of 1500 to $1200 \mathrm{~m}$ this accumulation layer of undecayed organic matter gradually becomes thinner and assumes the normal features of an $\mathbf{A}_{00}$ - plus $\mathbf{A}_{0}$-layer.

\section{Object 14: Surroundings of Manokwari}

The discussion of the surroundings of Manokwari will be limited to the land east of the Pami river and to the coastal area southward to the Maroeni river (see FIG. 8). The Warmaré- and Prafi plains are discussed separately (Object 15).

Manokwari is situated on the southern border of a Pleistocene limestone landscape that extends along the north coast all the way westwarc to the mouth of the Prafi 
FIG. 8. Geological sketch map of the hinterland of Manokwari

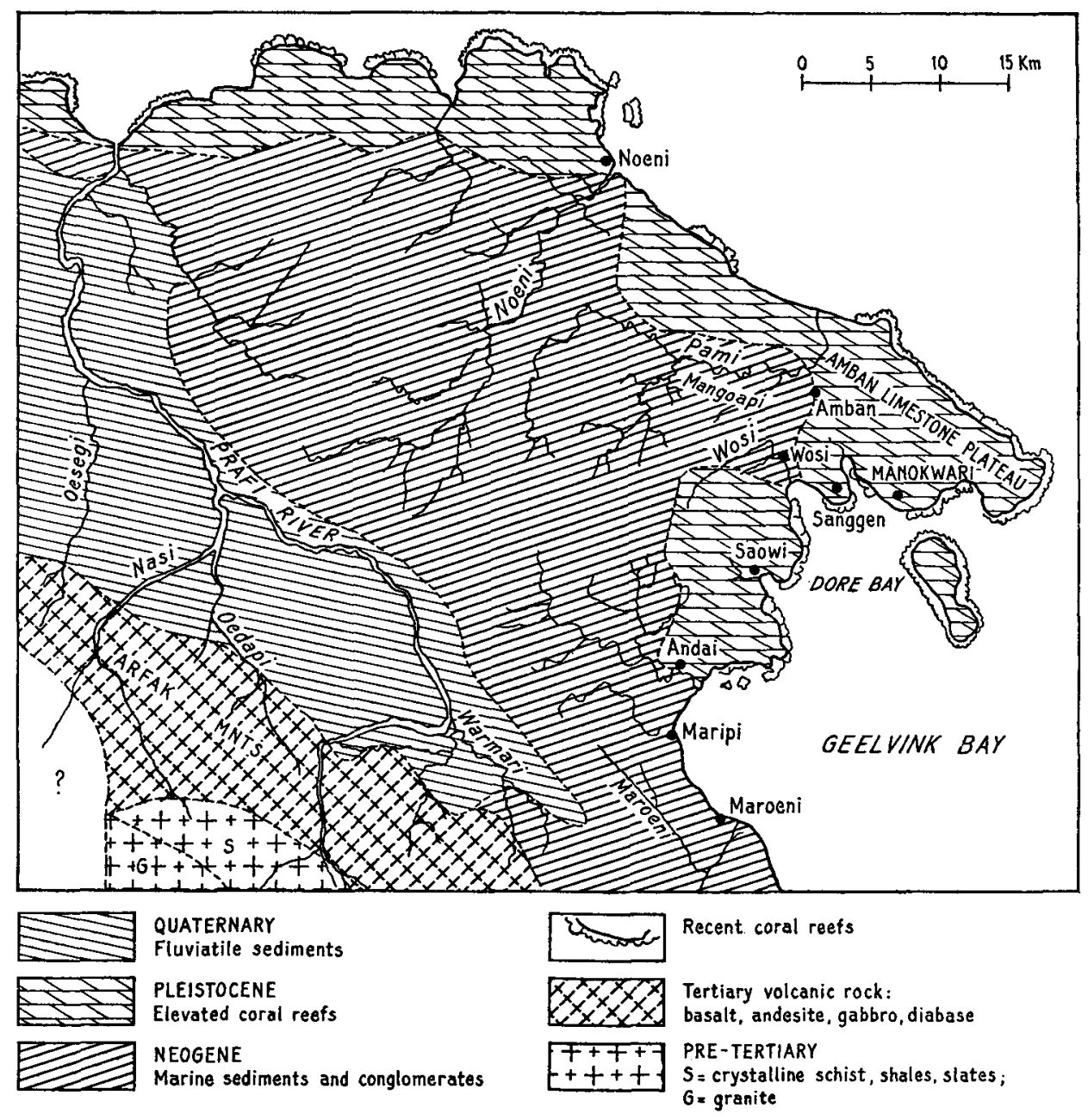

river. The limestone area consists of elevated coral-reef terraces. Its highest platform, defined by the $70 \mathrm{~m}$ form-line, is called the Amban plateau. On the plateau a very shallow, dark reddish-brown (5 YR. 3/4) limestone soil is found that is similar to the already described Biak soil. Locally, in pockets of the limestone, a deeper phase of a lighter reddish-brown colour (5 YR. 4/4) is found. The shallow phase is slightly alkaline because of small fragments of limestone grit, whereas the deeper phase is more leached and slightly acidic. These soils are also characterized by unusually high phosphate contents which vary from 1 to $3 \%$. Because the limestone involved is not a very pure type of calcium-carbonate rock the potash content of the soil is not so low as has been diagnosed elsewhere. As most of the Amban soils are under growth of secundary forest, the humus fertility of these soils is high and they are accordingly very much liked by the natives for the growing 
of food-crops. Especially on the shallow phase, the thin layer of available soil is characterized by a high humus content and an accumulation of nutrients which is not found on the deeper soil phase. A good example of a standard (averaged) analysis of the upper $15 \mathrm{~cm}$ of such shallow soils is presented in ANNEX III. Of course, the very high figure for available potash is not reflected by the figure for total potash, which remains low. These soils are used for only one or two years by the natives. When exposed to the heat of the sun, the organic matter burns away very quickly and the soil tends to dry out irreversibly. By then the soil aggregates become gritty as they are cemented and hardened by iron oxide. In this condition the soils do not hold moisture and are very pervious to rainwater.

About 250 ha of this limestone soil are found on the Amban plateau, outside the Forest Arboretum Reserve. About 100 ha of this same type of soil occurs north of the river Andai. Here, its colour is strong brown (7 YR. 5/6) and the undeep, stony phase predominates. The Pleistocene limestone landscape is bordered in the west by a Plio-Pleistocene formation of hilly land. Its bedrock consists mainly of calcareous and non-calcareous, lightly consolidated marine sediments varying in texture from sands to clays. Locally, especially in the southern part, these sediments are interspaced with conglomerate beds, the rock fragments of which are derived from the older mountain massif, far south, where a great variety of bedrock occurs (FIG. 8). According to WentHol (Report 14.1), the whole of the 25.000 ha of hilly country, which lies west of the limestone area, east of the Noeni river and north of the Prafi river, is covered with one type of soil which is described as a brownish-to reddishyellow, loamy soil of the latosolic type.

It is believed that another 50.000 ha of this same soil covers the hilly country west of the Noeni river. The broken type of country is not very favourable for agricultural enterprise. Moreover, the soils are very susceptible to erosion. This fact accounts for the observation of WENTHOLT that the solum is generally shallow, and weathered bedrock ( $\mathrm{C}_{1}$-layer) is often found close to the soil's surface. Only two variants were distinguished, namely, the brownish-yellow type on the finer-textured parent materials and the reddish-yellow type on the conglomerates. As the mineralogical make-up of the latter group of parent materials is different from the marine sedimentary materials, it is obvious that the soil variants $1 \mathrm{a}$ and $1 \mathrm{~b}$, as distinguished by WENTHOLT, actually are two separate soil series each with different characteristics. Likewise, it is to be expected that more soil types and soil phases will present themselves when the area is mapped in more detail, so that Wentholt's soil not actually will be a soil association.

This soil association is best known through one of its soil series, namely the Mangoapi, strong brown (7.5 YR. 5/6) deep, sandy to silty loam. Some hundred hectares of this soil are found in the Mangoapi area which lies at the same level as the Amban limestone plateau and directly west of it.

The soil has been used for market-gardening by European small-farmers. After one or two years of good yields, deterioration set in quickly because of the exhaustion of humus fertility. The soil is lacking structure. After rains, the surface of the soil tends to become sealed by a thin impervious film of dispersed clay- and silt particles. Not only that organic manures are essential for improvement and maintenance of its physical proporties, but also nitrogenous and phosphatic fertilizers are badly needed on this soil. Generally, the soil is well supplied with potash as it contains biotite along with the less weatherable minerals orthoclase and muscovite. Luxury consumption of potash and deficiency of phosphate have been clearly demonstrated by 
leaf-analytical data derived from a fertilizer trial with cocoa on this soil by ScHroo (1960). A standard analysis is presented in ANINEX III and refers to an average of 25 analyses carried out on soil samples taken from an experimental plot on the Amban plateau.

A variant of this soil type is found on the limestone terraces which lie between the Amban plateau and the shore. It appears that the reef plateaus, when still submerged, were covered with Pami sediments. After elevation of the land, this layer of sediments has been preserved from wash by the protuding rim of coral limestone which surrounds the terraces. The texture of these terrace soils also varies from sandy to silty loams and the chemical analysis is also subject to variations depending on the mineralogical framework of the sedimentary material.

Another related soil association is formed by the various soils found on the higher terraces of the Moeni-, Pami-, Wosi-, Andai- and other small rivers; the lower terraces are frequently flooded.

In the experimental cocoa area Wosi, about 90 ha of this soil type occur, partly on the higher terrace and partly on the lower terrace. The latter is more fertile. The texture of these predominantly light yellow-brown (10 YR. 6/4) soils varies widely in horizontal and in vertical direction. In some spots impervious layers of sticky clay in the subsoil may obstruct the drainage of the soils. Most profiles contain small amounts of free lime and, accordingly, a slightly alkaline reaction (see ANNEX III). The only area which deserves some more attention in the surroundings of Manokwari is the Andai coastal plain. Here, about 100 ha of a deep, greyish, loamy sand and 230 ha of a deep, greyish loam occupy the greater part of this level terrain, which is very wet because of poor drainage and occasional flooding of the Andai river. After appropiate, technical improvements, some 300 ha of suitable soils are to be found here.

On the landside, the area is surrounded by limestone hills which carry the wellknown shallow limestone soils. Along the hill-foot a strong brown (7.5 YR. 5/6) sandy loam is found on the slopes of the transitional zone between the limestone hills and the alluvial flat.

The Maroeni plain, still farther south, may be reckoned to the southern-most outpost of our object 14. It occupies a few thousand hectares but is so stony and rocky that it must be considered unsuitable for any type of agricultural use.

Reviewing the surroundings of Manokwari we must conclude that the surface area of all soils suitable for present use probably amounts to not much more than 500 ha, scattered over various localities. Until medio 1963, the greater part of these soils was occupied by small-farmers and by experimental farms. Another 500 ha may be reclaimed for future use by means of flood protection, drainage and manures.

The areas Amban, Mangoapi, Wosi, Andai and the land in between, are all surveyed and mapped in detail $(1: 20.000)$. Elaborate soil descriptions are presented in the original reports sub. 14.

Object 15: Warmaré- and Prafi plains (FIG. 8)

The Warmaré plain can be reached from Maroeni by a track of $12 \mathrm{~km}$ length. It may be regarded as a natural extension towards the Prafi plain of the Manokwari hinterland. In connection with the limited agricultural possibilities around Manokwari and the desirability to open up new land for the settlement of people of the Arfak mountain-tribes, the Warmaré- and Prafi plains were surveyed in semi-detail in 1959 and 1961 , respectively. 
The name "Warmaré plain" is a misnomer because the actual area involved comprises the various river terraces (bottoms) of the Lie river. The Lie is an affluent of the Prafi river, whereas the Warmaré is only a smaller tributary of the Lie.

The soils of the oldest (highest) river terraces and of the adjacent hillsides are brownish- to reddish-yellow, silty loams, which probably belong to the same soil association of soil family as the terrace soils of the Pami, Wosi, Andai and the other rivers mentioned under object 14. The greater part of these soils, however, is unsuitable, being shallow, stony and badly eroded. The deeper phases which do not form large areas, are rather sticky and heavy loams, often, with impervious subsoils like those observed in Wosi.

About 200 ha of suitable soils are found in the higher part of the lower river terrace which may represent second-bottom land and is only very occasionnally subject to flooding. Further down the river and closer to the confluence with the Prafi river, soils are permanently wet and frequently flooded. The suitable soils mentioned, are dark yellowish-brown, fine-sandy to silty loams. They are commonly deep, friable, pervious soils with a well-developed organic surface layer. The subsoil often contains layers of medium-fine sand or fine gravel which improves the internal drainage of the solum. The soil reaction is slightly acidic, the lime-, magnesia- and phosphate sontents are very good but the potash content is too low (see analysis, ANNEX III). The Prafi plain is a real flood-plain 18.000 ha of which have been surveyed and mapped on a scale of $1: 50.000$. The length of this area is $25 \mathrm{~km}$ whereas its average width, measured between the mountain massif in the south and the PlioPleistocene hilly country in the north, is about $7,5 \mathrm{~km}$. The up-stream part of the plain lies at $200 \mathrm{~m}$ above sea level, the northwestern end of the surveyed area attains only an altitude of $30 \mathrm{~m}$. The Prafi plain merges farther northwest, into the Warjori plain. Together, these two plains form a large geosynclinal area, also called the Arfak plain, which has a general southeast-northwest trend. This synclinal depression has been filled with thick beds of detritus derived from the Arfak massif during the Pleistocene area.

After regression of the ocean and a consequently lowering of the erosion-base level of the north-coast rivers, the Prafi river has cut a new bedding into the unconsolidated sedimentary material and carried most of it away during the period in which her present flood-plain was formed. Meanwhile new transported material was deposited in this flood-plain by the Prafi and her affluents: Oedapi, Aimasi, Oesegi and others (see FIG. 8).

In the surveyed area, therefore, a primary distinction has been drawn between the old and the young alluvial parent materials. The old alluvial parent materials, also called "terrace gravels", are to be found along the southern border of the plain with the surrounding highland. They are also present still as isolated hills inside the plain which have survived the eroding forces of the rejuvenated rivers.

Due to their conglomerate structure, these old alluvial materials are generally well drained. They carry a brownish- to yellowish-red (5 YR. 4/6) sandy to silty loam which is seldom void of gravel below a depth of $25 \mathrm{~cm}$. Their textural composition and stoniness vary considerably from spot to spot as may be expected. Their mineralogical composition shows an advanced degree of weathering in comparison with the young alluvial soils. They are more acid and low in available lime and phosphate. Their potash content, however, is excellent (see ANNEX III). The soils are rated as suitable soils for a less-demanding tree crops like rubber, provided that the deeper phases are selected and the appropriate measures are taken to control erosion. It is 
estimated that about half of the total of 5.000 ha will suit this purpose.

The young alluvial soils (symbol A.J.) are also very heterogeneous as far as texture and stoniness are concerned. The area east of the Oedapi shows all the features of a detrital (alluvial) fan with irregular patches and strips of boulders and gravel at or near the soil surface.

Apart from these lithosols and from the flooded, first-bottom soils along the Prafi, two series of young alluvial soils are distinguished, mainly, on account of an averaged difference in texture of the upper $50 \mathrm{~cm}$ of soil. Both series are azonal types with little profile development and a general olive-brown $(2.5 \mathrm{Y} .4 / 4)$ colour. On an average, their mineralogical composition (sand fraction $500-50 \mu$ ) does not vary much but clearly contrasts to that of the Old Terrace soils :

\begin{tabular}{|c|c|c|}
\hline $\begin{array}{l}\text { Groups of minerals } \\
\text { supplying : }\end{array}$ & $\begin{array}{l}\text { Old terrace } \\
\text { soils }\end{array}$ & $\begin{array}{l}\text { Young alluvial } \\
\text { soils }\end{array}$ \\
\hline potassium $\ldots \ldots \ldots \ldots \ldots$ & 11 & 17 \\
\hline sodium $\ldots$. & 1 & 4 \\
\hline calcium $\ldots \ldots \ldots \ldots$ & 0 & 2 \\
\hline calcium + magnesium $\ldots \ldots$ & 2 & 9 \\
\hline phosphorus $\ldots \ldots \ldots \ldots \ldots$ & 0 & traces \\
\hline rock fragments $\ldots \ldots \ldots \ldots$ & 6 & 7 \\
\hline $\begin{array}{l}\text { inert components } \ldots \ldots \ldots \ldots \\
\quad \text { (quartz, oxides, etc.) }\end{array}$ & 80 & 61 \\
\hline Total & 100 & 100 \\
\hline
\end{tabular}

The soils are very fertile according to the averaged analyses of both of two series, presented in ANNEX III. The series A.J.1. is found predominantly in the southern half of the plain and comprises the sandy to silty loams whereas the second series A.J.2. in the northern part of the plain comprises silty loams, silts, silty clay loams and clay loams. The soils of the second series also contain, on an average, less gravel and of a finer type. They also contain in their subsoils layers of a heavy clay at a depth of one metre or more, which may be an old basin clay as described by Edelman (1950) for the Netherlands.

Summarizing the results of the Prafi-plain survey, it is assumed that besides the 2.500 ha of Old Terrace soils already mentioned, about 3.000 ha of suitable young alluvial soils of a very good quality are available.

The depth of gravelly subsoil layers will be the most important mapping criterium for further detailed soil surveys. A very useful soil map $(1: 50.000)$ is contained in report 15.3.

\subsection{Northern part of Vogelkop Peninsula (Objects 16-20)}

\section{Object 16: Coastal plain near Sidai}

In 1955, a coastal area of 2.200 ha situated between Cape Kaironi in the west and the Jori river (War Jori) in the east was surveyed and mapped on a scale of $1: 50.000$, in which 12 different soil types were distinguished.

Only 180 ha, occupied by a yellowish-brown (10 YR. 5/4-7/6) sandy loam (No. 4) and another $50 \mathrm{ha}$, occupied by greyish beach sands (No. 10) are rated suitable for present use. As a matter of fact, the greater part of this area is already used for cropping by the local population.

About 300 ha occupied by five different soil types, are unsuitable because of relief, 
stoniness and infertility. The remaining 1.720 ha of swampy and marshy land have hydromorphic soils of a silty-loamy texture. Analytical data are not available. This low-lying area which is separated from the sea by an elevated stony sand beach, could possibly be reclaimed by proper drainage measures and protection against excessive inflow of surface water from the higher hinterland.

\section{Object 17: Amberbaken coast}

In 1933, the Amberbaken coast with the adjacent mountain sides, situated between the kampongs of Waibeem and Saukorem, measuring 25 by $25 \mathrm{~km}$ in length and width, was surveyed on a reconnaissance scale of $1: 100.000$.

The actual coastal plain is narrow and is intersected by salients of the unnamed mountain massif which rises steeply up from the coast. Inside the rugged mountainous area that was surveyed altitudes do not exceed $500 \mathrm{~m}$, although further inland the mountains reach up to heights around $2.000 \mathrm{~m}$. As far as soil-forming parent materials are concerned, it can be said that the predominant bedrock in these mountains consists of old-volcanic andesites and andesitic conglomerate beds. On cape Saukorem and west of Waibeem, Neogene tuffaceous sandstones are found, whereas two small areas of Quaternary reef limestones occur near Wefiani and Waibeem. In the mountains, below an altitude of $1.000 \mathrm{~m}$ reddish-brown to yellowish-brown latosols are reported to develop on highly silicified and propylitisized andesites. Mostly, the profiles are truncated by erosion down to the mottled subsoil layer or even to the parent rock. Complete profiles are found in the few level terrains on mountain ridges. They show a crumbly upper layer over a pale-red to rust-brown and whitemottled sub-layer. Lateritic concretions were not found in these profiles. These deeper soils are judged suitable for cropping purposes, although no analytical data are available at present. Most of these suitable soils below an altitude of $700 \mathrm{~m}$ are already occupied by the native population. Above $1.000 \mathrm{~m}$, soils of the podsolilc type become predominant.

Down in the narrow coastal belt which is not much wider than one kilometre on an average, six different soil types are distinguished, which belong partly to marine and partly to fluviatile sedimentary soils.

The various young rivers which carry a heavy load of detritus from the steep mountain areas, traverse the foot-hills and coastal plain with a very short lower course and, consequently, deposit most of their coarser detritus right on the spot where the gradient diminishes, giving rise to the formation of alluvial fans (soil type No. 10). Much sandy material, however, has been carried into the sea providing there the building material for an off-shore bar. As a result of recent elevations of the northcoast region, some more off-shore bars could arise. Together, these stony sand ridges form a protecting beach wall in front of the coastal lagoons. The latter have subsequently been filled with finer fluviatile sediments on which azonal soils of a loamy to clayey texture are being formed. These soils are very fertile, having a neutral reaction, high contents of available lime, magnesia, potash and phosphate and a good mineral reserve. However, all soils are already in use by the native population, some of them are even permanently cropped without a fallow period.

Object 18: Kebar plains (FIG. 9)

The Kebar plain is situated $30 \mathrm{~km}$ south of the Amberbaken coast at an average altitude of $500 \mathrm{~m}$ above sea level. The plain measures $40 \mathrm{~km}$ in length, has a width varying from 2 to $7 \mathrm{~km}$ and is on all sides enclosed by rugged mountainous land. 


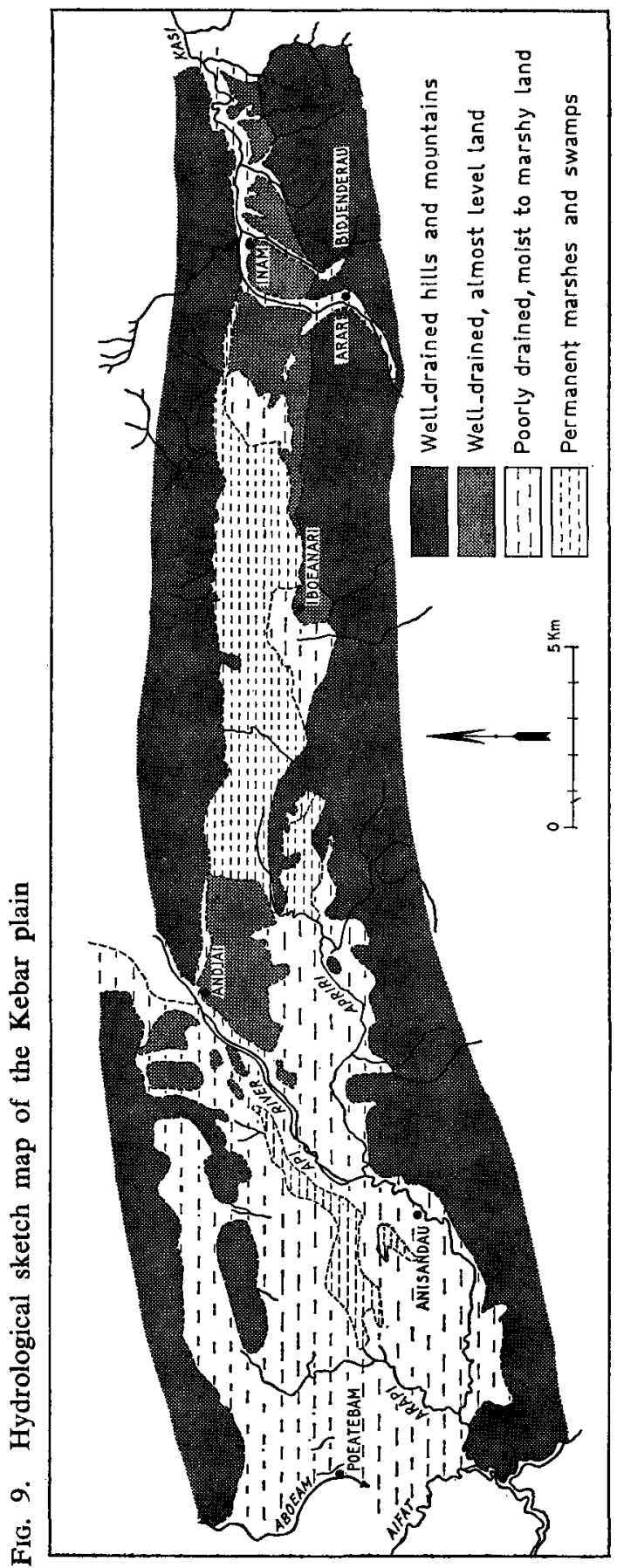

Neth. J. agric. Sci., Vol. 11 (1963) No. 5 (November) 
According to the geologist MolengraAFF (1954), the Kebar plain must be regarded as a "graben" or fault trough which has slipped downwards along the east-west striking Tamrau-Kebar fault on north, the Aremi fault on south, and the Aifat fault which strikes northwest-southeast, on its western border. Afterwards, this fault trough became a lake.

The lake was fed in its western part by the rivers Aifat and Api which carried predominantly granitic detritus from the northern mountain massif. In the eastern part of the Kebar lake detritus from the southern mountain areas was deposited, which consist mainly of quartzitic shales and sandstones.

After the Aifat river in the west had cut a new outlet southwards to the MacGluer Gulf, and the Kasi river in the easternmost part of the lake had found a bedding towards the Pacific Ocean along the afore-mentioned fault, the Kebar lake was largely drained. At present, only the central part of the plain, and also an old bedding of the Api river in the western part, are still swamp areas.

The Kebar plain was surveyed in 1958 (Report 18.1) when about 36.000 ha were mapped on a scale of 1:50.000. A soil map, a land-use map, a vegetation map and a hydrological map were produced. The soil map contains 22 mapping units, which are partly soil complexes and partly soil series. These units are assembled into three major physio-graphic soil groups, namely 16.000 ha of mountain soils (B), 15.000 ha of fertile soils of the western Kebar plain (Vw), and 5.000 ha of rather infertile soils of the eastern Kebar plain (Vo).

The group of mountain soils are found in the nearest surroundings of the plain, and consist of three soil complexes, viz. 5.000 ha of limestone soils (B. 1), 8.000 ha of sandstone soils (B. 2), and about 3.000 ha of soils developed on sandstone and shale (B. 3).

The soils of the group B. 1 developed on the soft Negone limestones which are found mainly along the northern border of the plain, are quite different from the soils developed on coral limestones, as described for Biak and Manokwari.

They possess a crumby, greyish coloured, organic surface layer of $15 \mathrm{~cm}$ depth, overlying a light greyish-brown $(2.5 \mathrm{Y} .6 / 5)$ stiff loam which becomes tougher as the depth increases andd may contain soft blackish concretions. The soils are found in steep terrain and they are quite often truncated.

The complex of red-yellow podsolic soils developed on Jurassic sandstones are found on the northeastern mountain side along the southern border in the middle of the plain. It is here, that the southern fault cuts straight through the sandstone, forming a remarkable linear ridge, bordering the plain. The steep surface of the fault facing the plain, exposes the brownish- and purplish-stained layers of sandstone. The soils developed on this parent rock show a greyish coloured, organic surface layer of about $10 \mathrm{~cm}$, overlying a yellowish-brown loamy $\mathrm{B}_{1}$-horizon, followed downwards by a yellowish-red $\mathrm{B}_{2}$-horizon of a loamy clay that is brightly red-mottled and contains large siliceous concretions. This horizon gradually merges into a $\mathbf{B}_{3}$ and $C_{1}$, which become paler and more colourless nearer to the fresh parent rock. The bright colours of the subsoil are more pronounced on high spots and steep slopes, even under dense forest. The third soil complex $\left(\mathbf{B}_{3}\right)$ of mountain soils is very much related to soil complex B. 2. Generally they are steep, shallow and stony soils.

The lower mountain sides adjacent to the plain are partly covered with forest and, especially in the southern hills, with grass savannas which are put on fire for hunting purposes every year.

Generally speaking, it can be assumed that most of the mountainous land is suitable 
for forestry and dairying only. Extensive grass areas are also found in the plain. On the vegetation map those grass areas, which are valuated as suitable pastures, have been indicated, and grass analyses have been presented in Report 18.1. All together, an estimated 5.000 ha of pastures of medium quality are available in the plain and surrounding hills.

The two other physiographic soil groups ( $\mathrm{Vw}$ and $\mathrm{Vo}$ ), occurring in the plain proper are defined by their geographic position in the western and eastern part of the plain, and also by their differentiated mineralogical and chemical characteristics.

Although exceptions to the general rule are observed, it may be said that, on the whole, the eastern soils are decalcified, more acid and of a poorer mineralogical composition. In the eastern soils, quartz, ores and rock fragments may take up as much as $95 \%$ of the sand separates. In the western soils, this percentage of inert material is less than 25 , whereas the bulk of the sand separates consists of pyroxene, amphibole, feldspar, biotite and muscovite. It is beyond the scope of this paper to review in detail the characteristics of the 10 soil units distinguished in the western, and the 9 soil units distinguished in the eastern group of alluvial soils. Moreover, some of these units are of a complex and heterogeneous character, and the corresponding analytical data are rather inconsistent, changing considerably from spot to spot. As a general guide to the complexity of these lacustrine and fluviatile soils, it may be noted that the soil suitabilities in the Kebar plain are often restricted by infertility, extreme stoniness and shallowness, coarse-sandy layers in uppersoil or subsoil, permanent swampiness, frequent temporary wetness because of terrain conditions and the occurrence of impervious clayey soil layers at or near the soil surface.

The annual rainfall amounts to $1.800 \mathrm{~mm}$ (72 inches) divided over 110 rainy days. This means that large amounts of rainwater may accumulate in a few days in level, poorly drained terrains, whereas during a dry spell of some duration, the coarsesandy soils dry out completely. These sandy and stony soils which are susceptible to drought are all covered with a grass vegetation which never regenerates back to forest again.

The bulk of the better soils which can be made suitable for the growing of commercial crops after proper drainage of the terrain, are found in the western part of the plain, between the rivers Apriri and Aboeam. These soils are loamy sands and sandy loams which are still under forest. Their soil reaction is acidic, the content of available nutrients is quite good.

The Truog figures for available phosphate vary considerably around an average value of 15 p.p.m. $\mathrm{P}_{2} \mathrm{O}_{5}$. The phosphate tends to accumulate in the surface soil under forest growth and values of 100 to 300 p.p.m. $\mathrm{P}_{2} \mathrm{O}_{5}$ are not uncommon for humic surface soils. A standard analysis which presents the calculated average of ten surface soils with subsoils sampled near Senopi (West Kebar), are presented in ANNEX III. Although the total-potash contents of all 20 samples are high to very high, the values for available potash do not exceed 100 p.p.m. which is low indeed.

This discussion may be concluded with a summary of the recommendations made for land use in this area of 36.000 ha: 3.000 ha unsuitable soils, 2.000 ha poor pasture soils, 3.000 ha fairly good pasture soils, 14.000 ha forest soils in the plain which can be made suitable for commercial cropping, 14.000 ha forest soils in the surrounding hills and mountains which are suitable for forestry only.

Object 19: Coast near Sausapor

Medio 1962, an area of 15.000 ha east of Sausapor was surveyed on a reconnaissance scale of $1: 100.000$. Due to the departure of the surveyor and the closing of 
the Bureau of Soils, the results of this survey have not been regularly reported. Four valleys of the Oenai-, Nowai-, Wenai- and Koor rivers were visited. Only in the valley of the War Oenai about 300 ha of suitable dry soils could be found, whereas swamp conditions were found in the other valleys. Along the Koor river very narrow, gravelly terraces occur which are dry but of too small extent.

Generally, the mountainous area shows steep slopes and a very much dissected pattern. East of Sausapor, a plateau-like landscape is found near the coast which is separated from the mountain area farther inland by a long, narrow-shaped swamp. The plateau consists of Jurassic limestone and conglomerate beds with andesitic material. The limestone soils are nowhere deeper, and mostly less than $75 \mathrm{~cm}$ deep. Sinkholes are common in this karst terrain. The soils developed on conglomerate are very deep and of a compact, clayey type. About 700 ha of suitable soils are available in this area. Another 700 ha of suitable clayey soils developed on shales, were found in a medium-high hilly landscape near the kampong of Wenai.

Object 20: The hinterland of Sorong (FIG. 10)

Originally, the town of Sorong was built on the small island of Doom. Gradually, most activities of Government and commerce were moved to the small village of Remoe on the mainland opposite Doom. In the following account Sorong on the mainland ( $=$ Remoe) will be meant, when speaking of the town of Sorong.

In the near surroundings of the town and in other areas farther away, there appears to be very little opportunity for agricultural enterprise. Even in the years when Sorong was the seat of the oil-company (N.N.G.P.M.) and there was a great demand of vegetables and fruit with the population, the company never succeeded in her attempts to get the local production of marketing crops starting. Eventually, all foodstuffs had to be purchased and flown-in from remote markets, a circumstance that characterized the situation. The area south of Sorong which is the alluvial plain of Remoe, is extremely swampy and is bordered on its coastal side by Mangrove swamps.

The area north of Sorong is occupied by steep and dissected mountains of old volcanic origin, and of medium heights varying between 300 and $500 \mathrm{~m}$. This long stretched, Pre-Tertiary andesitic formation follows the north coast all the way from Cape Sorong eastwards to the Dore Hoem Bay. Between the steep mountain sides and the sea-shore but little space is left. The coast east of Cape Sorong was surveyed over a length of about $6 \mathrm{~km}$ in 1960 (Report 20.3), when only 50 to $100 \mathrm{ha}$ of rather infertile soils could be recommended for cropping purposes. The dominant soil type which covers the greater part of the andesitic mountain complex is a bright red (2.5 YR. 5/6), latosolic, deep, friable silty loam with a yellow-mottled concretionary clayey subsoil. The parent material, consisting of andesitic rock or breccia's, is thoroughly weathered, quartz being at present the only recognizable mineral. An analysis of three horizons of a typical profile of this soil (No. 1) near the kampong of Sauka is presented in ANNEX III.

The soils are mostly truncated by erosion and parent rock often lies bare at the surface. The deeper phases occurring on sheltered sites are qualified by an excellent structure and, if the humic surface layer is preserved, they possess a certain degree of fertility. This humus fertility is very soon exhausted after the soil is cultivated. The remaining soil is very acid and depleted of plant nutrients.

The mountain range along the north coast is broken through in its middle by the War Samson, a big river which has a large drainage basin and rises more than 


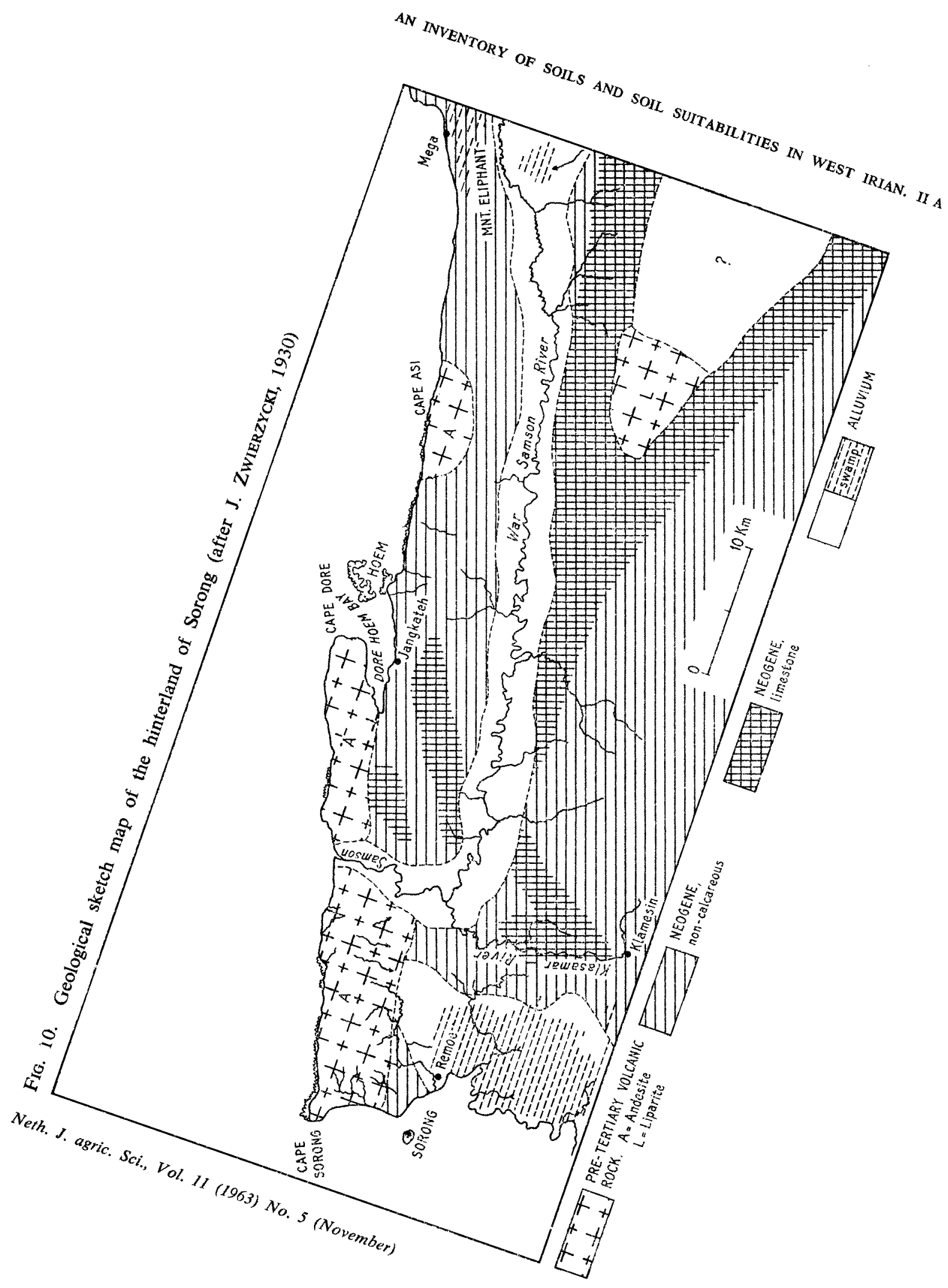


$100 \mathrm{~km}$ eastwards in the Tamrau Mountains. Its course follows the long east-west fault across the northern Vogelkop which is also followed by the Isjon-, Wasami-, Api- and Kasi rivers, each of which is running in the prolongation of the others.

The river is joined by quite a number of tributaries and thus collects more water than easely can be discharged through the narrow passage in the northern mountain ranges. Consequently, a broad flood-plain has been formed which is frequently flooded. A quick rise of the water of $5 \mathrm{~m}$ and more is not uncommon when heavy rains fall in the drainage area, but the disposal of these flood-waters is not so quickly accomplished.

The longitudal plain which stretches east-west is not entirely flat, but is divided into a northern and southern part by an intersected chain of hills and ridges, presenting the remnants of Neogene bedrock that also encloses the plain on all sides. The slow-flowing, meandering river is found one time on the north-, one time on the south side of the dividing elevations which form even so many obstacles to the drainage of the plain. The width of the plain is estimated to be $5 \mathrm{~km}$ on an average and its length measures $75 \mathrm{~km}$. The plain can be reached across hilly country at a distance of $20 \mathrm{~km}$ in straight eastern direction from Sorong. At this site the War Samson joins with the Klasaman river and follows with a sharp turn the southnorthern direction of this affluent.

A reconnaissance survey carried out as far back as the year 1935, resulted in the mapping of a strip of land which was about $1 \mathrm{~km}$ wide and more than $140 \mathrm{~km}$ long. The surveyed strip followed a trail leading from Sorong across the War Samson towards the kampong of Jangketek at the Dore Hoem Bay. From there, it went straight south back to the War Samson, and from there followed this river upstreams, until the farmost point was reached near Mega on the north coast. In 1949, a second reconnaissance party followed the same trail up to the crossing with the Samson river. From there it followed this river up streams and, subsequently, the Klasaman river up streams in order to swing westwards back to Sorong (Reports 20.1 and 20.2).

Both surveys are typical examples of the old fashioned "strip-surveys", as discussed in Part I. Although 23 different soil types were distinguished and entered into the fragmentary soil map, the connection between the various soil boundaries remained obscure and an estimate of surface areas occupied by the soil types outside the surveyed strip is not possible. Nevertheless, a certain amount of information about an otherwise unknown area has emerged from these two surveys.

From FIG. 10 it follows that the War Samson plain is surrounded on all sides by a Neogene landscape. South of the plain, mainly Neogene limestones occur which are covered by shallow, brown limestone soils of the type already discussed for Biak. These limestone soils and the karst features of this Neogene landscape will be more fully described when dealing with the Ajamaroe region (Object 21) (Part II B).

North of the plain, tuffaceous sandstones, quartzitic sandstones and mudstones predominate, whereas breccia's are found in the western and eastern parts of the Neogene mountains ranges. The prevailing soil type is a yellow to yellowish-red, podsolic soil (No. 3), which includes two soil variants and also various phases of graveliness of the subsoil. The two variants occur intermingled in the terrain. One is formed on clay stone and is a yellowish-red loam with a light brownish-grey surface soil, a bleached, red- and yellow-mottled subsoil which overlies a $\mathrm{C}_{1}$ - and C-horizon of clay stone (No. 3a). This variant occupies the larger area of the two. The other variant (No. 3b) is developed on (tuffaceous) sandstone containing much 
quartz. The composition of its profile is similar to the preceding one, but the reddish colouring is absent and also the yellowish mottling of the bleached subsoil is only faintly tinged pinkish. At present, the soils are void of bases and are extremely acid, having a pH of 5,0 or even lower. This soil is also found in the Neogene landscape west of the plain between the Klasaman river and the coastal swamps. Due to its leached and infertile character this soil type is unsuitable for cropping purposes and has to remain under forest, like soil type No. 1 (the red latosol on andesite) which has already been discussed.

Besides these two soils No. 1 and No. 3 and the brown limestone soils No. 6, there is one more soil of the hills and mountains to be discussed.

This soil No. 15 is found in smaller and larger areas as a river-bottom soil in the Neogene landscape north of the War Samson. It is a young, fluviatile, yellow, sandy loam with faint profile development. It often has a finer-textured, rather compact and imperious, yellowish-brown sub-layer. The soil is found in the valleys and a rather plain-like area west of the Dore Hoem Bay, where it occupies 800 ha of bottom land, most of which needs additional drainage measures. The soil which is fairly fertile is also found in patches on the levees of the Klasaman river but is reported to be more calcareous here because the Klasaman river traverses limestone country.

Another 200 to 300 ha of drainable land covered with this type of soil is to be found on higher ground along the Ramoi- and Kalagoesam rivulets, east of Remoe (Sorong). It is different from the yellowish clay which covers most of the poorly drained lowland south and east of Remoe. The latter soil (No. 18) is only suitable for the growth of sago. An average analysis worked out for 8 pairs of samples taken from surface soil and subsoil near Remoe are presented in ANNEX III. The mineralogical reserves of this clay are nil.

In the actual flood-plain of the War Samson larger areas are unsuitable for agriculture because of marshiness, swampiness or flood hazard. A suitable soil (No. 10) which is found above flood level, covers some thousand hectares in the western half of the plain at both sides of the river. It is a light brownish-grey loam of moderate fertility. Its subsoil is bleached and becomes heavier and "gleyed" deeper down into the profile. In some instances clay stones were found underneath but no explanation has been offered as to the question whether this is a residual or a transported soil. The other soils listed in Report 12.1 must remain undiscussed because they are unsuitable or occupy scattered small areas. 
H. SCHROO

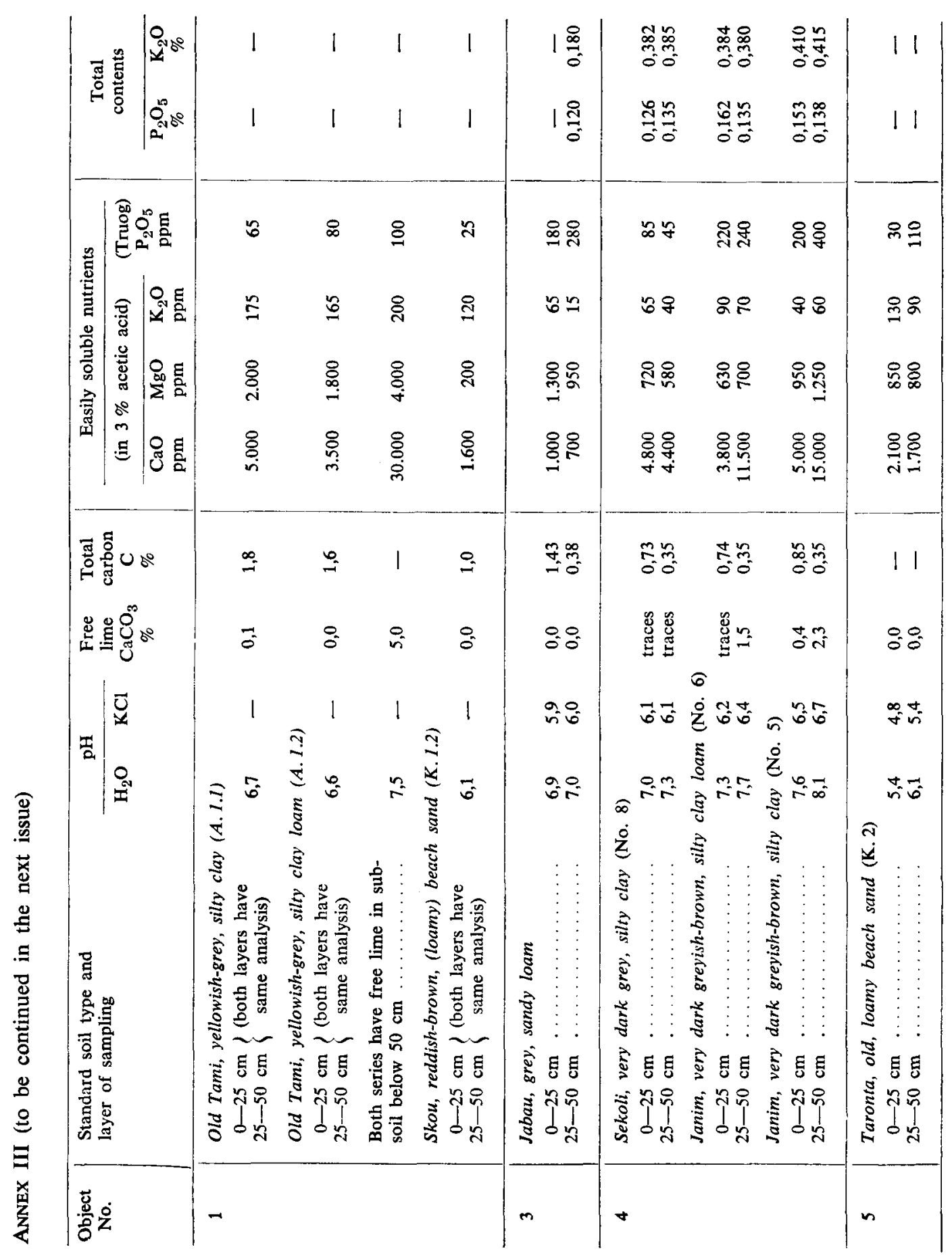


AN INVENTORY OF SOILS AND SOIL SUITABILITIES IN WEST IRIAN. II A

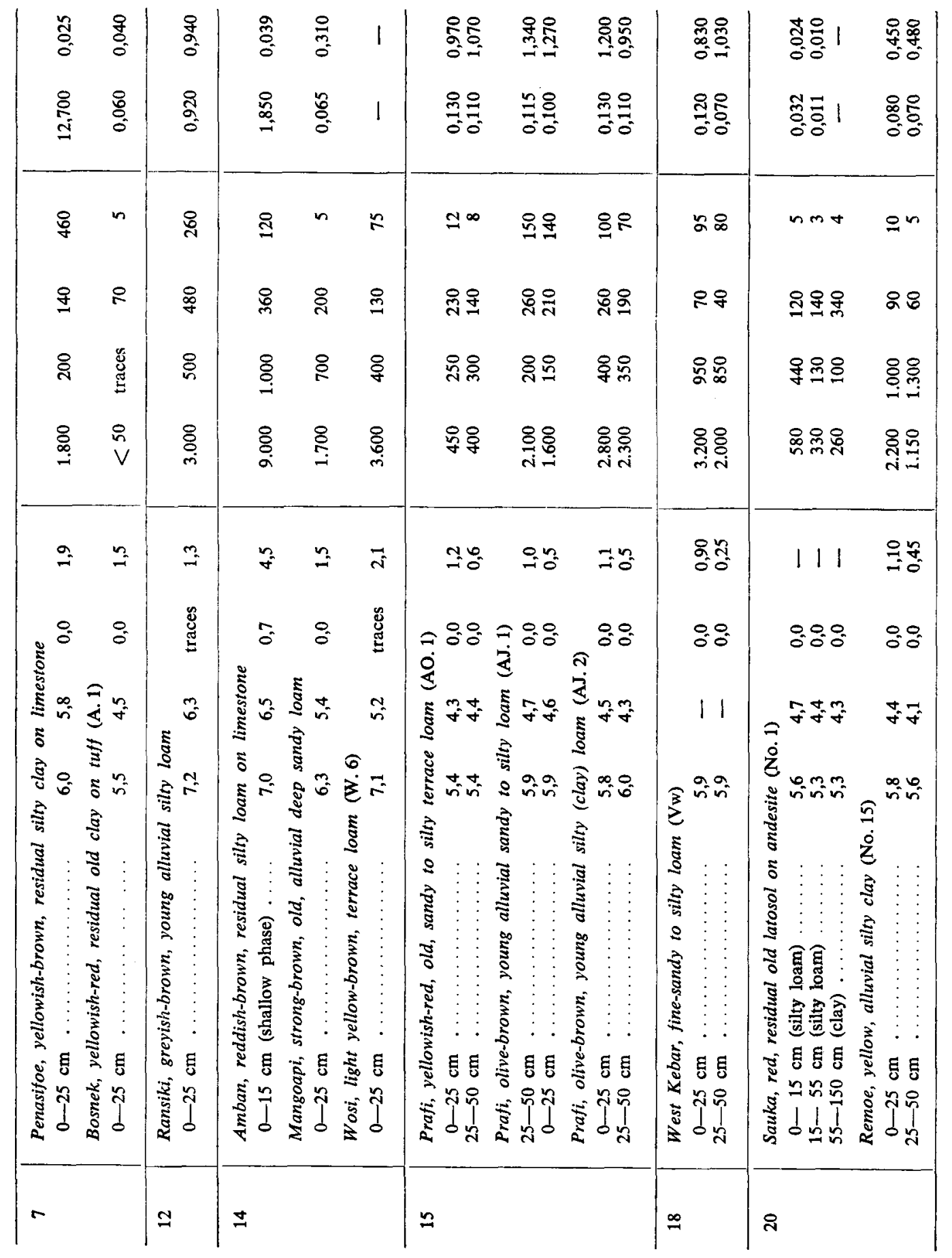

Neth. J. agric. Sci., Vol. 11 (1963) No. 5 (November) 